\title{
ARTISTS AND UNCONSTITUTIONAL CONDITIONS: THE BIG BAD WOLF WON'T SUBSIDIZE LITTLE RED RIDING HOOD'S INDECENT ART
}

\author{
MichaEl J. Elston*
}

INTRODUCTION

This article discusses recent developments in an area of the law analyzed in a 1990 Law and Contemporary Problems symposium, Freedom and Tenure in the Academy: The Fiftieth Anniversary of the 1940 Statement of Principles. ${ }^{1}$ Professor Robert O'Neil's article in that symposium examined the relationship between academic freedom and artistic expression, considering First Amendment protection for artistic expression as well as the particular problem of government funding of the arts. ${ }^{2}$ The controversy raised by the subject of government funding has "elevated the arts to an unaccustomed level of political visibility"3 and focused attention on the ongoing debate over unconstitutional conditions. As Professor O'Neil recognized, the restrictions placed on funded artists in the form of decency requirements have a "potential chilling effect" on "bold and controversial works" affecting both the artists themselves and the display industry of museums and galleries. ${ }^{4}$ Professor O'Neil argued that the decency requirement should be scrutinized as a potentially unconstitutional condition. ${ }^{5}$ He concluded that artistic freedom is closely intertwined with academic freedom,

Copyright (c) 1993 by Law and Contemporary Problems

* J.D. candidate, Duke University School of Law, May 1994.

The title is adapted from Chief Justice Rehnquist's dissenting opinion in FCC v. League of Women Voters, 468 U.S. 364, 402-03 (1984) ("In the Court's scenario the Big Bad Wolf [government] cruelly forbids Little Red Riding Hood [benefit recipient] to take to her grandmother some of the food that she is carrying in her basket .... [A] truer picture of the litigants [is] that some of the food in the basket was given to Little Red Riding Hood by the Big Bad Wolf himself, and that the Big Bad Wolf had told Little Red Riding Hood in advance that if she accepted his food she would have to abide by his conditions.").

The author gratefully acknowledges the advice, assistance, and support of Professor William Van Alstyne, Professor Rodney Smolla, Professor Neal Devins, Susan Sweet Elston, and Barbara and Gerald Emanuel, as well as the cooperation of the ACLU Foundation of Southern California, the Center for Constitutional Rights (New York) and Mark W. Batten of the U.S. Department of Justice.

1. 53 LAW \& CONTEMP. PROBS. (Summer 1990), reprinted in FREEDOM AND TENURE IN THE ACADEMY (William W. Van Alstyne ed., 1992).

2. Robert M. O'Neil, Artistic Freedom and Academic Freedom, 53 LAW \& CONTEMP. PROBS. 177 (Summer 1990). O'Neil assumes that artistic expression, short of being legally obscene, enjoys the full protection of the First Amendment regardless of political content or lack thereof. The dimensions of the constitutional protection for artistic expression, however, are far from clear. See id. at 177-82.

3. Id. at 187.

4. Id. at $189,190$.

5. Id. at 190-91. 
and that control of the purse strings should not permit the government to control artistic expression any more than it permits control of professors in a statefunded classroom." $"$

This article also complements Professor John Garvey's analysis of Congress's recent decisions about the National Endowment for the Arts ("NEA"), the principal government entity providing public support for the arts." As Professor Garvey noted, "whether the NEA actually can control the content of speech that it pays for is a hard First Amendment question." article was "more interested in the approach [of courts] than the solution" and in contrasting that approach to constitutional decisionmaking with that of Congress, this article analyzes proposed solutions to the hard question and offers two new, mutually exclusive, solutions of its own.

The extent of government's power to condition the receipt of benefits on the renunciation of a constitutionally protected right is unclear under current Supreme Court jurisprudence. This lack of clarity, in turn, chills the constitutionally protected activities of benefit recipients because they are not sure whether the conditions attached are permissible. While some conditions are said to be constitutional and others are not, a principled, coherent, and honest distinction between the two types has eluded scholars and jurists alike. Such a state of affairs is unacceptable for a society governed by law and is unworthy of the Constitution. The rule of law requires that like cases be treated alike, and this general principle is reflected in the Constitution. ${ }^{10}$ When courts fail to interpret the law to require the government to act "in a principled and coherent manner toward all its citizens," the law lacks integrity and fails to extend "to everyone the substantive standards of justice or fairness it uses for some." 11 Integrity is lacking because the Constitution, as interpreted in the unconstitutional conditions decisions, permits society to enact and enforce "different laws each of which is coherent in itself, but which cannot be defended together as expressing a coherent ranking of different principles of justice or fairness . ..."12 One goal of this article is to offer a method of introducing integrity into this area of the law.

Part II of this article considers the application of the doctrine of unconstitutional conditions in the context of government funding for artistic expression through the NEA. It analyzes the most relevant, potentially conflicting lines of authority represented by Rust v. Sullivan ${ }^{13}$ and Keyishian v. Board of Re-

6. Id. at 193.

7. John H. Garvey, Black and White Images, 56 LAW \& CONTEMP. PROBS. 189 (Autumn 1993).

8. Id.

9. Id. at 198 .

10. The Equal Protection Clause prohibits a state from denying "to any person within its jurisdiction the equal protection of the laws." U.S. CONST. amend. XIV, \& 1 . See RONALD DwORKIN, LAw'S EMPIRE 184-85 (1986) (arguing that the clause reflects the important political ideal of "integrity," an essential component of the collective political morality of the United States).

11. DwORKIN, supra note 10 , at 165 .

12. Id. at 184 .

13. 111 S. Ct. 1759 (1991). 
gents. ${ }^{14}$ Part III analyzes the doctrine of unconstitutional conditions generally, including its origins as a reaction against the "right-privilege distinction." It also considers scholarly attempts to explain the underpinnings of this doctrine, both generally and in the context of government funding of the arts, and suggests an alternative explanation. Part IV concludes that a neutral application of an internally consistent, and intellectually honest, unconstitutional conditions doctrine will result in advantages for proponents and opponents alike. Additionally, this article argues that such a doctrine is the most desirable outcome under the Constitution.

II

FEDERAL CONDITIONS ON FUNDING FOR THE ARTS

Congress shall make no law . . abridging the freedom of speech $\ldots{ }^{15}$

Implementing the command of the First Amendment is difficult because, as with many provisions of our Constitution, the right to freedom of speech runs counter to basic human instincts. It is more an aspiration than a reality. What is a child's first reaction to something he or she does not want to hear? "Shut up!" One's instincts are to silence those who would say or do something of which one does not approve. History, ancient and modern, abounds with examples of the suppression of disapproved speech. Most recently, the "far right" of the U.S. political spectrum has used its political influence to suppress expression as varied as speech concerning abortion and flag burning. ${ }^{16}$ These efforts have historically failed, but usually only after great effort, expense, and bloodshed.

Throughout the history of the United States, however, Congress and the state legislatures have not complied with the command of the First Amendment, and the Supreme Court has, from time to time, acquiesced in legislative restrictions. ${ }^{17}$ Freedom of speech does not mean, of course, that each citizen has the right to say whatever he or she wishes. For example, criminal liability may constitutionally be predicated on words "which by their very utterance inflict

14. 85 U.S. 589 (1967).

15. U.S. CoNSr. amend. I.

16. See 42 C.F.R. \$ 59.8(a)(1) (1992) (prohibiting federally funded family planning clinics from engaging in abortion counseling), suspended by Memorandum of the President to the Secretary of Health and Human Services, 58 Fed. Reg. 7455 (1993).

Texas law criminalized the desecration of a sacred object, including the United States flag. Tex. PENAl CODE ANN. \$ 42.09(a)(3) (West 1989). The Supreme Court held the statute unconstitutional as an unjustified abridgement of protected expressive conduct. Texas v. Johnson, 491 U.S. 397 (1989).

17. See, e.g., Sedition Act of 1798, 1 Stat. 596 (expired by its terms in 1801) (though never tested in the Supreme Court, there is general agreement that the statute violated the First Amendment); Dennis v. United States, 341 U.S. 494, 501-11 (1951) (affirming convictions for mere advocacy of the overthrow of the government). 
injury"18 or speech which is "directed to inciting or producing imminent lawless action" if such a result is likely. ${ }^{19}$ First Amendment jurisprudence, then, consists largely of various decisions dividing speech and expression into protected and unprotected classes, and dividing restrictions on protected speech into permissible and impermissible categories. The scope of this article is limited to protected expression, the prohibition of which is impermissible.

The government has other tools at its disposal, however, to achieve impermissible ends. When frustrated by the First Amendment in attempts to prohibit a type of speech or expression, it may resort to subtler means. Modern government dispenses public benefits worth billions of dollars annually. The benefits range from public employment to financial aid for college students. Government can condition the receipt of these benefits by requiring the recipient to surrender something in return. However, when the surrendered item is the right to exercise a constitutionally protected freedom, courts and legal scholars have taken two radically different views as to the legitimacy of the condition.

Some begin the analysis of the problem from the proposition that the government need not offer the benefit at all. It follows, they argue, that the government can attach any condition it chooses without regard to the impact of the exercise of constitutionally protected rights. This viewpoint is labeled the "right-privilege distinction," and it is discussed in section IIIA below.

Others argue that the analysis should begin with the result of the conditioned-benefit offer. They would ask whether the offer may result in a citizen forgoing a constitutionally protected activity that the government could not directly prohibit through legislation. If so, opponents of the right-privilege distinction argue that the condition is unconstitutional because the Constitution does not permit the government to achieve by indirect means what it could not achieve directly. This viewpoint is known as the "doctrine of unconstitutional conditions," discussed in section IIIB below.

The problem of an unconstitutional condition can arise in a variety of unique settings. One area in which the problem of a potentially unconstitutional condition has arisen is in connection with the government's financial support of the activities of artists. The primary vehicle for this support is the NEA, established by Congress in 1965 as a constituent part of the National Foundation on the Arts and the Humanities. ${ }^{20}$ The NEA chairperson is advised by the National Council on the Arts, a group of private citizens appointed by the president. The goals of the NEA are to foster artistic excellence by enhancing the nation's creative talent, to promote availability of the arts, to maintain the nation's cultural legacy, and to stimulate private support for the arts. It has twelve program areas that range from dance to rural and inner city arts. ${ }^{21}$ The

18. Chaplinsky v. New Hampshire, 315 U.S. 568, 572 (1942).

19. Brandenburg v. Ohio, 395 U.S. 444, 447 (1969).

20. The National Foundation on the Arts and the Humanities Act, Pub. L. No. 89-209, 79 Stat. 845 (1965).

21. Id. 
1993 fiscal year appropriation for the NEA was nearly $\$ 176$ million, ${ }^{22}$ down from its 1988 fiscal year appropriation of more than $\$ 177$ million. $^{23}$

Taste in art may be subjective, but with that much money at stake, it is not surprising that taste in art became explosive and controversial. ${ }^{24}$ In 1989, Congress adopted the short-lived Helms Amendment, requiring grant recipients to swear under oath that they would not produce or display art that could be considered homoerotic or sadomasochistic or that showed "individuals engaged in sex acts." 25 When renewal of the NEA was being considered the next year, liberal and conservative lawmakers reached a compromise. Still in force, the compromise language requires that grant applications and applicants meet "general standards of decency and respect for the diverse beliefs and values of the American public." 26 In other words, the Big Bad Wolf will not let Little Red Riding Hood create indecent artwork because some of the tools in her bag were purchased with money given to her by the Big Bad Wolf.

Questions about the constitutionality of the "decency clause" arose soon after its adoption ${ }^{27}$ and remain unresolved. ${ }^{28}$ Can the Big Bad Wolf really prevent Little Red Riding Hood from producing constitutionally protected works of art just because he bought some of her paint and brushes? A federal district court in California faced that question for the first time last year and tried to muddle through the Supreme Court's incongruous precedents.

\section{A. Finley v. NEA}

The plaintiffs in Finley v. $N E A^{29}$ fell into three groups: (1) artists who had applied or planned to apply for NEA grants subject to the decency clause, ${ }^{30}$ (2) artists who were deterred from applying for grants by the decency clause; and (3) the National Association of Artists' Organizations, whose members fell into both

22. H.R. REP. No. 901, 102d Cong., 2d Sess. (1992), the House-Senate conference report, allowed $\$ 175,955,000$ for the NEA.

23. Susan Boren, Congressional Research Service, ArTs, Humanities, and Museums: AUTHORIZATIONS, APPROPRIATIONS AND BUDGET REQUESTS 4 (1992).

24. See, e.g., Kim Masters, NEA Chief Defends Grant Vetoes: Further Conflicts Likely, Radice Says, WASH. POST, May 29, 1992, at D1, D6; Stephen Salisbury, NEA Rejects 3 Grants for Gay Film Festivals, PHILA. INQUIRER, Nov. 21, 1992, at A1, A4.

25. Act of Oct. 23, 1989, Pub. L. No. 101-121, \& 304(a), 101 Stat. 701, 741. These restrictions were held to be unconstitutionally vague and overbroad in Bella Lewitzky Dance Foundation v. Frohnmayer, 754 F. Supp. 774 (C.D. Cal. 1991).

26. Department of the Interior and Related Agencies Appropriations Act, Pub. L. No. 101-512, \& 103(b), 104 Stat. 1915, 1963-66 (1990) (codified as amended at 20 U.S.C. $\S 954$ (d) (Supp. IV 1993)). The statute provides as follows:

$[T]$ he Chairperson shall ensure that $-(1)$ artistic excellence and artistic merit are the criteria by which applications are judged, taking into consideration general standards of decency and respect for the diverse beliefs and values of the American public.

27. See, e.g., O'Neil, supra note 2 , at 190.

28. The Supreme Court has not ruled on the constitutionality of 20 U.S.C. $\S 954$ (d).

29. 795 F. Supp. 1457 (C.D. Cal. 1992).

30. 20 U.S.C. \$ 954(d)(1). See supra note 26. 
of the other two categories. ${ }^{31}$ The plaintiffs offered two basic arguments for invalidating the decency clause. First, the plaintiffs assaulted the regulations as an unconstitutional condition on the receipt of government benefits because the recipients were required to curtail the exercise of First Amendment freedoms in all of their activities, whether funded by an NEA grant or not. ${ }^{32}$ Second, the plaintiffs characterized the regulations as impermissibly discriminating on the basis of the expression's viewpoint. The First Amendment prohibits such discrimination in certain contexts, such as university classrooms, where the government must act neutrally even when funding the expression. The plaintiffs argued that artistic expression was a similar context requiring the same protection. ${ }^{33}$

While admitting that the decency clause "may pressure prospective recipients to adopt the choice that the government prefers," ${ }^{34}$ the NEA contended that the decency clause was merely a nonsubsidy. Throughout its brief, the government refers not to unconstitutional conditions, but to unconstitutional penalties-assuming that a condition is constitutionally permissible unless it penalizes the exercise of a protected freedom. The government distinguished between a penalty and a nonsubsidy by stating that "[a]n unconstitutional penalty exists only when government seeks to limit the recipient's use of private resources to support the same activity, or attaches speech-related conditions to benefits that have nothing to do with speech."35 The NEA's denial of grants under the Decency Clause, therefore, is a nonsubsidy rather than a penalty because "the NEA never conditions its awards on the plaintiffs' agreement to avoid certain topics when they speak with private funds" and "an NEA grant is a specific subsidy for the particular purpose of subsidizing expression." ${ }^{36}$ The government argued that "[s]imply put," Congress's "“decision not to subsidize the exercise of a fundamental right does not infringe the right,' even if the government also chooses to subsidize some competing alternative(s)." 37

The district court held that the Decency Clause violated the First Amendment for overbreadth, as it "sweeps within its ambit speech and artistic expression which is [sic] protected by the First Amendment." 38 Relying on a

31. Plaintiffs' Memorandum of Points and Authorities in Support of Motion for Partial Summary Judgment at 8, Finley v. NEA, 795 F. Supp. 1457 (C.D. Cal. 1992) (No. CV 90-5236 AWT) [hereinafter Plaintiffs' Supporting Memorandum].

32. Id. at 22-24 (The decency clause "requires those who seek NEA funding to refrain from creating or presenting any art that conflicts with 'general standards of decency and respect for the diverse beliefs and values of the American people,' even if that art is created entirely with non-federal funds." (emphasis in original)).

33. Id. at 25-31.

34. Memorandum in Support of Defendants' Motion for Judgment on the Pleadings at 16, Finley (No. CV 90-5236 AWT) [hereinafter Defendants' Supporting Memorandum].

35. Id. at 19 (citing, inter alia, Rust v. Sullivan, 111 S. Ct. 1759, 1774 (1991); Harris v. McRae, 448 U.S. 297, 317 n.19 (1980); Maher v. Roe, 432 U.S. 464, $474-75$ n.8 (1977)).

36. Id. at 20-21.

37. Id. at 18 (citation omitted).

38. Finley v. NEA, 795 F. Supp. 1457, 1476 (C.D. Cal. 1992). 
loophole left by the Supreme Court in Rust $v$. Sullivan, ${ }^{39}$ the court found that "[a]rtistic expression, no less than academic speech or journalism, is at the core of a democratic society's cultural and political vitality," a "'traditional sphere of free expression ... fundamental to the functioning of our society.""41 The court also noted the "close relationship between academic freedom and artistic expression" and explicitly accepted the plaintiffs' analogy of funding for the arts to funding for public universities. ${ }^{42}$ The court held that, while allocation of limited public funds necessarily entailed some content-based decisions, the government is not permitted "to impose whatever restrictions it pleases on speech in a public university, nor should it [be permitted] such license in the arts funding context." ${ }^{, 43}$ The court continued as follows:

Hiring and promotion decisions based on professional evaluations of academic merit are permissible in a public university setting, but decisions based on vague criteria or intended to suppress unpopular expression are not. Analogously, professional evaluations of artistic merit are permissible, but decisions based on the wholly subjective criterion of "decency" are not. ${ }^{44}$

Attempting to avoid the morass of the unconstitutional conditions doctrine, however, the court ignored the fact that the NEA distributes a benefit and held that the statute was a direct "suppress[ion of] speech that is offensive to some in society." 45 Rather than analyzing this as an unconstitutional conditions problem, ${ }^{46}$ the court simply concluded that the "decency clause clearly reaches a substantial amount of protected speech" and that the general overbreadth doctrine of the First Amendment applies so that the statute "cannot be given effect." ${ }^{\prime 47}$ But the government never contended that the decency clause only reached the legally obscene (expression that is not protected by the First Amendment). ${ }^{48}$ The court missed the real issue in the case: whether the "government could achieve indirectly"-through conditioning funding on a

39. "[F]unding by the Government, even when coupled with the freedom of the fund recipients to speak outside the scope of the Government-funded project, is [not] invariably sufficient to justify government control over the content of expression." Rust v. Sullivan, 111 S. Ct. 1759, 1776 (1991).

40. Finley, 795 F. Supp. at 1473 (borrowing directly from Plaintiffs' Supporting Memorandum at 2829, Finley (No. CV 90-5236 AWT)).

41. Id. (quoting Rust v. Sullivan, $111 \mathrm{~S}$. Ct. at 1776).

42. Id. at 1474,1475 .

43. Id. at 1475 .

44. Id. (citations omitted).

45. Id.

46. Earlier in the opinion, the Court wrote that plaintiffs contended that "[f]irst ... the decency clause constitutes an unconstitutional condition. They argue that [point] because the NEA reviews all of an applicant's prior work in determining whether the application meets that standard. Alternatively, plaintiffs contend that, even if the reach of the decency clause is limited to work funded by the NEA, public funding of the arts (like public funding in the context of a university or the press) requires government neutrality, a requirement violated by the decency clause." Id. at 1472 (emphasis added).

47. Id. at 1476.

48. The Supreme Court held in 1989 that "expression which is indecent but not obscene is protected by the First Amendment ...." Sable Communications of California, Inc. v. FCC, 492 U.S. 115, 126 (1989). 
showing of decency- "what it could not achieve directly" by a law prohibiting indecent artwork, the classic unconstitutional conditions problem. ${ }^{49}$ The court failed to employ a necessary analysis of the relevant authorities, and thus failed to resolve the question presented by Finley.

The two principal Supreme Court decisions that must be analyzed for a proper resolution of the issue in Finley are Rust v. Sullivan ${ }^{50}$ and Keyishian v. Board of Regents. ${ }^{51}$ Both Rust and Keyishian are unconstitutional conditions cases, but they come to different conclusions. The resolution of the question presented by Finley depends, in part, on whether the facts are more closely analogous to Rust or to Keyishian.

\section{B. Free Speech in Government-Funded Private Programs: Rust v. Sullivan}

The 5-4 decision in Rust v. Sullivan ${ }^{52}$ is the Supreme Court's most recent and comprehensive analysis of free speech in the context of a federally funded program. The program at issue involved federal support for family planning services under Title $X$ of the Public Health Service Act. ${ }^{53}$ The Act provided that the funds were not to be used "where abortion is a method of family planning." 54 In 1988, the Health and Human Services Department issued new and controversial regulations under the statute that interpreted the statutory restriction more comprehensively, placing additional restrictions on funded projects. One provision required that funded projects and their employees "not provide counseling concerning the use of abortion as a method of family planning .....55 Similarly, the projects and their employees were forbidden to refer a pregnant woman to an abortion provider in response to a specific request about abortions. Instead, a permissible response to such a direct question would be that "the project does not consider abortion an appropriate method of family planning and therefore does not counsel or refer for abortion." 56 The restrictions applied to private, nonprofit organizations receiving Title $\mathrm{X}$ funds, regardless of the percentage of operating costs those funds represented. The regulations required that if an organization engaged in any prohibited abortion activities, those activities had to be "physically and financially separate" from the

49. See infra note 122 and accompanying text.

50. 111 S. Ct. 1759 (1991).

51. 385 U.S. 589 (1967).

52. 111 S. Ct. 1759.

53. 42 U.S.C. $\$ \S 300-300 a-6$ (1988). The Act, originally adopted in 1970 , authorizes the Secretary of Health and Human Services to "make grants to and enter into contracts with public or nonprofit private entities to assist in the establishment and operation of voluntary family planning projects which shall offer a broad range of acceptable and effective family planning methods and services." 42 U.S.C. $\S 300(a), 84$ Stat. 1506 (1970).

54. 42 U.S.C. $\& 300 \mathrm{a}-6$.

55. 42 C.F.R. \& 59.8(a)(1) (1992).

56. Id. $\S 59.8(\mathrm{~b})(5)$. 
funded programs. ${ }^{57}$ "Mere bookkeeping separation" would not be considered sufficient. ${ }^{58}$

The petitioners in Rust were funded projects and doctors who supervise funded projects, representing themselves and their patients. In their brief, written by Harvard Law School professors Laurence H. Tribe and Kathleen M. Sullivan, the petitioners argued that, among other things, these restrictions violated the First Amendment in several distinct ways. First, the restrictions were attacked as viewpoint-discriminatory conditions on government subsidies, "sprescrib[ing] what shall be orthodox." 59 Second, the petitioners argued that the restrictions penalize speech funded by private parties in two ways: first, any project funded in part by Title $X$ also receives funding from other, nonrestrictive sources; second, any non-Title $\mathrm{X}$ project operated by the same organization, funded entirely by unrestricted sources, is subject to the Title $\mathrm{X}$ regulations. ${ }^{60}$

The government, in a brief prepared by the staff of then U.S. Solicitor General Kenneth W. Starr, countered the petitioners' arguments by asserting that the regulations are content-based rather than viewpoint-based, that the government was merely acting as a "participant in the marketplace of ideas," and that its decision not to fund abortion-related speech was simply a refusal to subsidize speech about a single subject-abortion. ${ }^{61}$ The government denied that its regulations penalized anyone because grantees are free to decline the subsidy. ${ }^{62}$ However, once a grant recipient accepts the federal subsidy, it "is obligated to comply with the conditions of the federal grant," and the recipient's employees are obligated to follow the recipient's directives as a result of their voluntary employment relationship. ${ }^{63}$

At the same time, the government tried to distinguish this case from $F C C v$. League of Women Voters, ${ }^{64}$ where the Court struck down a requirement that public broadcasters not editorialize if they received federal funds, reasoning that the broadcasters could not feasibly segregate the federal funds. ${ }^{65}$ The most compelling and persuasive part of the government's brief was its recurring hypothetical example concerning a government-funded documentary on family planning techniques that excludes abortion information. The broadcaster contracting to produce the documentary was represented as being analogous to the Title X grantee, the broadcaster's employees were described as equivalent to the grantee's employees, and the audience was representative of the Title $\mathrm{X}$ project's clients. Surely, the government contended, Congress could choose to

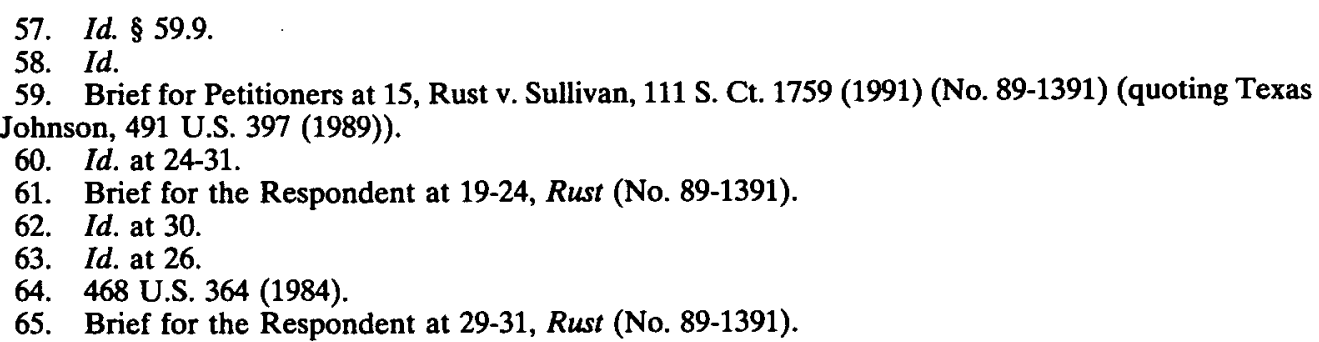


fund the documentary production as a participant in the marketplace of ideas without infringing upon anyone else's rights. The broadcaster may decline the contract, the employees can look elsewhere for work, and the audience may seek other sources of information. ${ }^{66}$

Just as the petitioners' arguments had some infirmities, the government's brief was not entirely persuasive. First, the distinctions made between content discrimination and viewpoint discrimination as well as those drawn between penalties and nonsubsidies are easily manipulated. As the petitioners argued, "redefining every conditioned grant or dispensation as a 'specific subsidized service' free of constitutional constraint would enable virtually any condition on a subsidy to escape . . . scrutiny . . ."67 For example, under the government's conception of the problem, the FCC would have prevailed in FCC v. League of Women Voters had they only characterized the funding program as subsidizing editorial-free public broadcasting projects. ${ }^{68}$ Second, the government's "participation" in the marketplace of ideas in Rust differs from participation in the form of funding and producing a documentary film. The government may certainly purchase television time to promote alternatives to abortion as an exercise. It is another matter, however, to permit the government to criminalize abortion or to withhold funds from clinics that permit their employees to discuss abortion. Alternatively, the argument that the government is acting merely as a participant in the marketplace of ideas can be thwarted by redefining the market. If the market is only family planning for low-income women, the government is not merely a participant in the marketplace but such a dominant force that its conditional participation amounts to regulation. ${ }^{69}$

A majority of the Justices, however, found the government's arguments and characterizations more persuasive than those of the petitioner. Relying on Maher v. Roe, the Court held that "the government may 'make a value judgment favoring childbirth over abortion, and ... implement that judgment by the allocation of public funds." 70 The Court distinguished between a penalty and

66. Id. at $22-23,25,27-28,30$.

67. Reply Brief for Petitioners at 1-2, Rust (No. 89-1391) (citation omitted) (emphasis in original).

68. Id. at 2 n.3.

69. See Brief for Petitioners at 22, Rust (No. 89-1391) (citations omitted):

A woman who comes to a doctor working in an institution that receives Title $X$ funds, like all patients, believes that her doctor will give her full information about her legally available and medically appropriate options. She is neither told, nor can she typically afford, to seek a second opinion. In this context it is wholly unrealistic to treat the regulations as mandating one-sided speech that will be countered by speech on the other side in the private marketplace. Indeed ... those whom the suppression of health information "hits the hardest are the poor ... [who] are [among] the least able to learn, by shopping from . . . [clinic to clinic], where their scarce dollars are best spent" or which doctor they should trust. For the five million women seen annually in Title X clinics, the Secretary's chosen means of enforcing orthodoxy is indistinguishable from that which would result from an across-the-board criminal or regulatory ban on abortion counseling and referral.

70. Rust v. Sullivan, 111 S. Ct. 1759, 1772 (1991) (quoting Maher v. Roe, 432 U.S. 464, 474 (1977)). 
a nonsubsidy, stating that the former is merely a choice "to fund one activity to the exclusion of the other"71 or the right of the government to define the limits of a government-funded program, ${ }^{72}$ leaving grant recipients free to pursue protected activities outside the context of the program. A penalty, on the other hand, is a "direct state interference with a protected activity" on the grant recipient, so that he or she is effectively barred from engaging in the protected activity. ${ }^{74}$ The Court also rejected the argument that the restrictions penalized speech with non-Title $X$ funds, begging the question by stating that the funds are just subsidies, and that recipients are given the choice to decline the subsidies or accept them with the conditions attached. ${ }^{75}$

In essence, the Court in Rust adopted the right-privilege distinction in its reinvigorated form, the penalty-nonsubsidy distinction. ${ }^{76}$ The Court stated that "the general rule that the Government may choose not to subsidize speech applies with full force" when the nonsubsidized activities may still be conducted by the recipients outside the limits of the funded program. ${ }^{77}$ This conclusion is, however, not as obvious as the Court may have believed. Prior cases concerning subsidized speech in university settings do not limit the reach of the doctrine of unconstitutional conditions to situations where the conditions completely prohibit benefit recipients from engaging in a protected activity. A discussion of how the Rust Court attempted to distinguish these cases is postponed until the next section of this article.

\section{Free Speech in the Academy: Keyishian v. Board of Regents}

The seminal decision about unconstitutional, speech-related conditions on the employment of university professors is Keyishian v. Board of Regents, ${ }^{78}$ an opinion rendered twenty-four years before Rust $v$. Sullivan. New York statutes and regulations in force during the early 1960 s required professors employed by the State University of New York to certify in writing that they were not then Communists or, if they had been Communists in the past, that they had revealed that information to the president of the university system. ${ }^{79}$ The statute at issue required removal of state university professors for "the utterance of any treasonable or seditious word or words or the doing of any treasonable or seditious act or acts." ${ }^{80}$ After a detailed analysis of the statutory scheme, the Court concluded that it allowed the removal of professors for "mere advocacy

71. Id. at 1772 .

72. Id. at 1772-74 (government is "simply insisting that public funds be spent for the purposes for which they were authorized").

73. Id. at 1772 (quoting Maher v. Roe, 432 U.S. 464, 475 (1977)).

74. Id. at 1774 (distinguishing "our 'unconstitutional conditions' cases").

75. Id. at 1775 n.5.

76. See infra text accompanying notes 109-14.

77. Rust, $111 \mathrm{~S}$. Ct. at 1776.

78. 385 U.S. 589 (1967).

79. Id. at 592 .

80. N.Y. EDUC. LAW $\S \S 3021-22$ (McKinney 1981) (incorporating by reference N.Y. CIV. SERV. LAW $\S 105$ (McKinney 1983)). 
of abstract doctrine" or even the "distribution of matter 'containing' the doctrine," which the Court believed might include "histories ... tracing the background of the French, American or Russian revolutions." ${ }^{81}$ A professor could plausibly be removed under the statute for teaching his or her class "about the precepts of Marxism or the Declaration of Independence" since both equally reflect the doctrine of forceful overthrow of the government. ${ }^{82}$ Membership in the Communist Party, or failure to certify nonmembership, was considered prima facie evidence of disqualification for a teaching position at a state university under these statutes. ${ }^{83}$

The Court in Keyishian specifically rejected the right-privilege distinction, holding the conditions on public employment invalid, even though professors are "at liberty to retain their beliefs and associations and go elsewhere." ${ }^{\text {" In }}$ so doing, it overruled an earlier decision that had held that a teacher's "freedom of choice between membership in a [subversive or treasonous] organization and employment in the school system might be limited, but not his [or her] freedom of speech or assembly, except in the remote sense that limitation is inherent in every choice." ${ }^{\circ 5}$ The Court, borrowing language from an earlier unconstitutional conditions case, stated that "[i]t is too late in the day to doubt that the liberty of ... expression may be infringed by the denial of or placing of conditions upon a benefit or privilege." ${ }^{86}$

In the course of its opinion, however, the Court did not clearly express its theory of unconstitutional conditions. It stated that "legislation which sanctions membership unaccompanied by specific intent to further the unlawful goals of the organization or which is not active membership violates constitutional limitations." stifle fundamental personal liberties." "'88 As a result, two readings of Keyishian are possible with regard to the types of restrictions state universities may place on professors' speech. First, at a minimum, universities may not condition continued employment on a surrender of the right to speak in a constitutionally protected manner at all times, as the New York statutes did. It is possible to read Keyishian as saying nothing about the in-class restrictions a university might adopt. However, much of the Court's justification for the decision in Keyishian rested on the special concerns of professors in maintaining their academic

81. Keyishian, 385 U.S. at $600,601$.

82. Id. at 600 .

83. Id. at 605 .

84. Id. (quoting Adler v. Board of Educ., 342 U.S. 485, 492 (1952)). The state of New York relied heavily on Adler, quoting large portions of the case in its brief, which remains a classic manifestation of the right-privilege distinction: "It is clear that [teachers] have the right under our law to assemble, speak, think and believe as they will. It is equally clear that such persons have no right to work for the State in the school system on their own terms." Adler, 342 U.S. at 492, quoted in Brief for Appellees at 18, Keyishian v. Board of Regents, 385 U.S. 589 (1967) (No. 66-105) (citations omitted).

85. Adler, 342 U.S. at 493.

86. Keyishian, 385 U.S. at 606 (quoting Sherbert v. Verner, 374 U.S. 398, 404 (1963)).

87. Id. at 608 (emphasis added).

88. Id. at 602 (emphasis added). 
freedom and the concerns of society in maintaining universities as the quintessential marketplace of ideas. ${ }^{89}$ These concerns would not be addressed unless the Court intended to limit restrictions on in-class expression as well as outside speech and association. A broader reading of the opinion, then, is that professors in state schools may not be dismissed solely for engaging in activities protected by the First Amendment, in or out of the classroom. ${ }^{90}$

Despite the broad protection for the academic freedom of university professors given by Keyishian, the precedent is not dispositive on the question presented by the Finley case. Rust seems equally applicable to the facts of Finley. The question boils down to whether NEA-funded artists are more like employees of federally funded family planning clinics or professors in state universities. The answer to that question is inherently subjective, since either answer has some support in logic and in the precedents of the Court. Proponents of free artistic expression will always say that artists are more like professors, while opponents will characterize the facts so that artists appear analogous to doctors in an abortion clinic.

The jurisprudence represented by Rust and Keyishian lacks both consistency and integrity. In Rust and Keyishian, as well as Finley, the central issue is whether an individual's First Amendment right to free expression may be conditioned upon the receipt of a benefit. The primary difference between the plaintiffs in Rust and Keyishian, excluding the topic of the speech involved, is the occupation of the person asserting the right. Such a distinction seems rather arbitrary, but it has its basis in the historical development of the doctrine of unconstitutional conditions. The next part of this article considers that history as well as the scholarly attempts to explain the current state of the doctrine. In so doing, the next part argues that the present doctrine is not a doctrine at all, but rather the subjective preferential treatment of certain rights at the expense of others under the guise of a "doctrine."

89. See id. at 603 (citations omitted):

Our nation is deeply committed to safeguarding academic freedom, which is of transcendent value to all of us and not merely to the teachers concerned. That freedom is therefore a special concern of the First Amendment, which does not tolerate laws that cast a pall of orthodoxy over the classroom. "The vigilant protection of constitutional freedoms is nowhere more vital than in the community of American schools." The classroom is peculiarly the "marketplace of ideas."

The essentiality of freedom in the community of American universities is almost self-evident. No one should underestimate the vital role in a democracy that is played by those who guide and train our youth. To impose any straight jacket upon the intellectual leaders in our colleges and universities would imperil the future of our nation.

90. Unconstitutional conditions problems in the academy are live and ongoing. In February 1993, a graduate teaching associate at California State University-Northridge, Rupert Stechman, was removed for asking his students to draw nude self-portraits. After his faculty supervisor ordered the assignment canceled because it was "inappropriate," Stechman gave his students a choice between the self-portrait and a still life. About $90 \%$ of the students chose the nude self-portrait. Stechman was fired, and two days later 20 students barricaded themselves in the university president's office to protest his removal. Art Teacher Sparks Protest, ThE CHRONIClE (Duke Univ.), Mar. 22, 1993, at 4, 15. 


\section{III}

\section{UNCONSTITUTIONAL CONDITIONS}

\section{A. The Right-Privilege Distinction}

Although the Supreme Court distinguished between rights and privileges as early as $1839,{ }^{91}$ the classic statement of the right-privilege distinction was penned by Oliver Wendell Holmes, Jr., in 1892 while he was serving on the Massachusetts Supreme Judicial Court. Holmes approved the firing of a policeman for engaging in prohibited political activities on the job, writing that " $[t]$ he petitioner may have a constitutional right to talk politics, but he has no constitutional right to be a policeman. ... [The employee] takes his employment on the terms which are offered him." 92 Holmes considered public employment a privilege rather than a right because the government is not required to create jobs. Government conditions attached to a privilege are permissible, Holmes argued, even when they infringe constitutional rights. In other words, the broader power of the government to refuse to grant any benefit at all necessarily includes the lesser power to grant a benefit conditionally. Under the aegis of the right-privilege distinction, the government has unlimited power to regulate nonobligatory advantages, that is, government largess. Indeed, an honest and consistent application of the rule would make easy cases out of all disputes over conditional privileges because the government would always win. ${ }^{93}$

The obvious problem with the dichotomy of rights and privileges is that government may use this unlimited power to achieve harsh results. When pressed to its logical conclusion, the right-privilege distinction could legitimate excessive conditions on the exercise of constitutionally protected activities that stem from the core values of a free and democratic society. Individual freedoms could be swallowed whole by conditioned privileges, rendering substantial parts of the Bill of Rights meaningless. Reflecting these concerns, the Supreme Court has found some applications of the right-privilege distinction problematic despite Holmes's reasoning. The Court in one decision discovered that "[i]f the state may compel the surrender of one constitutional right as a condition of its favor, it may, in like manner, compel a surrender of all. It is inconceivable that guarantees embedded in the Constitution of the United States may thus be manipulated out of existence." 94 In fact, the right-privilege distinction has been relied upon to justify, among other things, evicting public housing tenants without a hearing, ${ }^{95}$ dismissing college professors and high school teachers for

91. Bank of Augusta v. Earle, 38 U.S. 519 (1839) (holding that because a state may exclude foreign corporations from doing business within the state, it may legally impose arbitrary and unreasonable conditions for entry).

92. McAuliffe v. Mayor of New Bedford, 29 N.E. 517, 517-18 (Mass. 1892).

93. Rodney A. SMOlla, Free SPEECH IN AN OPEN SOCIETY 181 (1992).

94. Frost \& Frost Trucking Co. v. Railroad Comm'n, 271 U.S. 583, 594 (1926).

95. Housing Auth. v. Thorpe, 148 S.E.2d 290 (N.C. 1966) (per curiam), vacated, 386 U.S. 670 (1967) (per curiam). 
refusal to sign a loyalty oath, ${ }^{96}$ firing a high school teacher for teaching evolution, ${ }^{97}$ and prohibiting police officers and fire fighters from joining labor unions. $^{98}$

As government largess has increased, so too has the potential for abuse. Government benefits available in the modern regulatory and welfare state are pervasive. ${ }^{99}$ This very article might not exist if government were permitted to buy up constitutional rights with impunity. Law students could be required to write only articles expressing approval of government policy as a condition of receiving federal financial assistance to attend law school. After all, there is no right to a Stafford or Perkins loan; it is but a privilege.

The harsh results encountered in cases strictly applying the right-privilege distinction led to criticism by scholars and circumvention by courts. The death of the right-privilege distinction has been proclaimed throughout the United States. ${ }^{100}$ Professor Rodney A. Smolla criticized the Holmesian view of the right-privilege distinction as "intolerable in a modern society that aspires to make itself genuinely open and free."101

Opponents of the right-privilege distinction have not been entirely successful, and recent years have seen a resurgence of the distinction in decisions of the Supreme Court. ${ }^{102}$ The distinction was not dead; it had only suffered setbacks from an onslaught of doctrines that distinguished rather than overruled. In 1968, Professor William Van Alstyne correctly identified this trend as an erosion effected by the doctrine of unconstitutional conditions, procedural due process, equal protection, and other methods of circumventing the right-privilege distinction without confronting it. ${ }^{103}$ This apparent death and resurrection has

96. Thorp v. Board of Trustees, 79 A.2d 462, 469 (N.J.), vacated, 342 U.S. 803 (1951) (high school teachers); Board of Regents v. Updegraff, 237 P.2d 131, 137-38 (Okla. 1951), rev'd, 344 U.S. 183 (1952) (college professors).

97. Scopes v. State, 289 S.W. 363, 364 (Tenn. 1927) (the "Scopes Monkey Trial").

98. Hickman v. City of Mobile, 53 So. 2d 752, 760-61 (Ala. 1951); City of Jackson v. McLeod, 24 So. 2d 319, 322 (Miss. 1946) (en banc).

99. SMOLLA, supra note 93, at 183 (noting that the "influence of government affiliation" is enormous in modern times); Gary A. Winters, Note, Unconstitutional Conditions as "Nonsubsidies": When Is Deference Inappropriate?, 80 GEO. L.J. 131 (1991) (stating that government has assumed a central role in the allocation of regulatory benefits and financial assistance). See generally Charles A. Reich, The New Property, 73 Yale L.J. 733 (1964).

100. See, e.g., Shapiro v. Thompson, 394 U.S. 618, 627 n.6 (1969); Kenai Peninsula Borough Sch. Dist. v. Kenai Peninsula Borough Sch. Dist. Classified Assoc., 590 P.2d 437, 440 (Alaska 1979) (A government may not "confer a statutory right or benefit and withdraw it when the beneficiary exercises a constitutional prerogative."); Brukiewa v. Police Comm'r, 263 A.2d 210, 218 (Md. 1970) (rejecting the right-privilege distinction in context of public employment). See generally William W. Van Alstyne, The Demise of the Right-Privilege Distinction in Constitutional Law, 81 HARV. L. REV. 1439 (1968).

101. SMOLLA, supra note 93, at 182.

102. See generally Rodney A. Smolla, The Reemergence of the Right-Privilege Distinction in Constitutional Law: The Price of Protesting Too Much, 35 STAN. L. REV. 69 (1982).

103. Van Alstyne, supra note 100, at 1445-58. For example, the result in McAuliffe v. Mayor of New Bedford has been discredited by a line of cases holding that government may not penalize or fire its employees for speech concerning public issues. See, e.g., Givhan v. Western Line Consol. Sch. Dist., 439 U.S. 410 (1979); Pickering v. Board of Educ., 391 U.S. 563 (1968); Keyishian v. Board of Regents, 385 U.S. 589 (1967). However, the trend of recent cases indicates that the rule is not absolute and that the right-privilege distinction is viable even in cases of public employment. See, e.g., Connick v. Myers, 461 
resulted in confusion. In some cases, the Supreme Court struck down conditions on benefits as unconstitutional penalties; in others, the Court approved conditions as mere nonsubsidies while at the same time affirming the death of the right-privilege distinction. ${ }^{104}$ The challenge for scholars and law students, as well as for courts considering the decency clause at issue in Finley, is to distinguish in advance the former cases from the latter. ${ }^{105}$

The right-privilege distinction first reasserted itself in the opinions of the Court at the intersection of government entitlements and procedural due process law. The Constitution guarantees citizens "due process of law" before the federal or state government takes their "life, liberty, or property."106 A literal interpretation of these words, it is argued, includes constitutional rights and formal, statutory, or contractual entitlements. The Court has held, however, that entitlements not formally protected may be withdrawn without due process protection. ${ }^{107}$ The Court has even indicated that a statute creating an entitlement can define the procedural protections available to its recipients. ${ }^{108}$ The distinction between a formally protected entitlement and an unprotected interest is, in essence, just a new way of stating the distinction between a right and a privilege.

The right-privilege dichotomy has more recently reached out beyond the procedural due process area. Its effect can be seen in determinations of whether the government is required to give certain benefits at all. For example, a woman has a limited right to terminate an unwanted pregnancy. ${ }^{109}$ However, government may provide financial assistance for economically disadvantaged women who choose to give birth while refusing to assist similarly situated women with

U.S. 138 (1983) (firing employee stating labor grievance does not infringe First Amendment); Snepp v. United States, 444 U.S. 507 (1980) (per curiam) (holding that CIA may require employees to submit writings on service for pre-publication review); U.S. Civil Service Comm'n v. National Assoc. of Letter Carriers, 413 U.S. 548 (1973) (upholding ban on political campaigning by federal government employees). But see Rutan v. Republican Party of Illinois, 497 U.S. 62 (1990) (prohibiting governor from firing lowerthan-policymaking-level state employees for political affiliation).

104. Smolla, supra note 102, at 69 (citing, inter alia, Board of Regents v. Roth, 408 U.S. 564, 571 (1972) (claiming right-privilege distinction had been "fully and finally rejected" while holding that an assistant professor with no expectation of rehiring does not have a property interest that requires the university to grant a hearing before deciding not to renew his contract)).

105. Comprehensive efforts have been made to identify the underlying principles relied upon by the Court in deciding whether a conditioned benefit is an unconstitutional penalty or a mere subsidy. For an excellent recent attempt, see Kathleen M. Sullivan, Unconstitutional Conditions, 102 HARV. L. REV. 1415 (1989). See infra text accompanying notes 171-80.

106. U.S. CONST. amends. V \& XIV, \& 1 . Due process generally requires that the government provide fair procedures for the factual and legal determinations that lead to a deprivation of life, liberty, or property. See, e.g., In re Murchison, 349 U.S. 133, 136 (1955) (holding that due process requires a "fair trial in a fair tribunal").

107. See Jago v. Van Curen, 454 U.S. 14 (1981) (holding that parole decision not a formal entitlement and can be reversed without a hearing).

108. See Cleveland Bd. of Educ. v. Loudermill, 470 U.S. 532, 538 (1985) ("Property interests are not created by the Constitution" but by independent sources such as state law, which also define the dimensions of the interest.); Bishop v. Wood, 426 U.S. 341, 345 (1976); Lerner v. Casey, 357 U.S. 468, $477-79$ (1958).

109. Roe v. Wade, 410 U.S. 113, 153 (1973). 
the expenses of an abortion. ${ }^{110}$ Freedom to choose an abortion is a right. Government funding of pregnancy-related expenses is a privilege, and may be offered on the condition that the recipient forgo exercising her right to have an abortion. The right-privilege distinction in these situations has been disguised with the language of subsidies and nonsubsidies. The decision not to fund certain things while funding others is a policy choice, merely a nonsubsidy. In other words, a citizen may have a right, but he or she does not have a right to have the exercise of that right subsidized; funding is a privilege.

Rust v. Sullivan, ${ }^{111}$ as discussed above, is a more recent example of an approved "nonsubsidy." The Court concluded that the government may validly choose to subsidize family planning services relating to childbirth, while choosing not to subsidize those relating to abortion. This nonsubsidy of protected speech does not violate the First Amendment because employees of funded programs, such as a family planning clinic, are free to discuss abortion with patients under the auspices of other programs of the clinic that do not receive federal funding. The restriction only ensures that funded activities are limited to the scope of the program authorized by statute, which did not include abortion counseling. ${ }^{112}$ In other words, the government's funding decision leaves employees in the same situation as if the government had chosen not to fund family planning services at all: they may speak about abortion but must turn to private sources for funding. ${ }^{113}$ While dressed up in different language, the Court is relying on the right-privilege distinction. ${ }^{114}$ Employees may have a right to speak about abortion, but government funding of its exercise is a privilege which may be conditioned or withheld completely.

It should not be surprising that the right-privilege distinction has reemerged to influence the feasibility and constitutionality of modern government entitlement programs. The roots of the distinction run deep and are a manifestation of the view that the Constitution guarantees negative liberties, or rights against government action, rather than granting positive rights to government benefits or action. ${ }^{115}$ The belief that the Constitution creates only

110. Harris v. McRae, 448 U.S. 297, 316-17 (1980). But see Right to Choose v. Byrne, 450 A.2d 925 , 941 (N.J. 1982) (holding that refusal to provide Medicaid funding for abortions to preserve the health of the mother violated equal protection clause of the state constitution since all childbirth costs are funded).

111. $111 \mathrm{~S}$. Ct. 1759 (1991). See supra text accompanying notes $52-77$ for a full discussion of Rust.

112. Rust, $111 \mathrm{~S}$. Ct. at $1774-75$

113. The Court did not explicitly rely on this rationale in the First Amendment context, but it did so in the analysis of the companion challenge that the regulations impermissibly infringed patients' right to choose an abortion. $111 \mathrm{~S}$. Ct. at 1777 . The Court has used the same rationale in other abortionfunding decisions. See Harris, 448 U.S. at 317; Maher v. Roe, 432 U.S. 464, 474 (1977).

114. In fact, the government's arguments to the Supreme Court drew heavily on the cases outlining the distinction between a nonsubsidy and a penalty (the right-privilege distinction). See Brief for Respondents at 20, Rust v. Sullivan, 111 S. Ct. 1759 (1991) (No. 89-1391) (citing Regan v. Taxation with Representation, 461 U.S. 540 (1983); Harris, 448 U.S. 297; Maher, 432 U.S. 464).

115. See, e.g., DeShaney v. Winnebago County Dep't of Social Services, 489 U.S. 189 (1989) (holding that the department was not liable, even after being informed repeatedly of the situation, for failure to act to prevent beatings of a child by his father that resulted in permanent brain damage, because the child was not in state custody and the injuries were inflicted by a private party). 
negative rights antedates the adoption of the Constitution itself ${ }^{116}$ and still spawns serious scholarly debate. ${ }^{117}$

Even with the reemergence of the right-privilege distinction under other names, there may be limits to its reach. It seems unlikely that the Supreme Court would permit the government to insist on any concession it chooses when distributing benefits. One potential limitation on the reach of the right-privilege distinction is the doctrine of unconstitutional conditions.

\section{B. The Doctrine of Unconstitutional Conditions}

The Supreme Court developed the doctrine of unconstitutional conditions out of concern that the power to condition the receipt of benefits could render constitutional protection of individual liberties meaningless. ${ }^{118}$ The classic statement of the doctrine is broad and antithetical to the right-privilege distinction. In Perry $v$. Sindermann, the Court explained that "even though a person has no 'right' to a valuable governmental benefit and even though the government may deny him the benefit for any number of reasons, there are some reasons upon which the government may not rely. It may not deny a benefit to a person on a basis that infringes his constitutionally protected interests . ..."119 In other words, the government may not achieve indirectly through conditioned benefits (that is, purchasing individual rights) what it could not achieve through direct regulation (that is, prohibiting the exercise of individual rights). ${ }^{120}$

116. See, e.g., THE FEDERALIST No. 84, at 573-76 (Alexander Hamilton) (Heritage Press 2d ed., 1973) (Hamilton describes several rights against the government incorporated into the body of the Constitution and asserts that, unlike MAGNA CARTA (June 15, 1215), the constitutional provisions are not "abridgements of prerogative [of the King] in favor of privilege [of the people]" but a "recognition of popular rights" "founded upon the power of the people" so that, strictly speaking, "the people surrender nothing ....").

117. See generally Susan Bandes, The Negative Constitution: A Critique, 88 MICH. L. REV. 2271 (1990) (exhaustive critical account of the negative rights view).

118. See Frost \& Frost Trucking Co. v. Railroad Comm'n, 271 U.S. 583, 593-94 (1926). The doctrine was foreshadowed as early as 1856 . See Lafayette Ins. Co. v. French, 59 U.S. (18 How.) 404,407 (1856) (Upholding the state's condition that a foreign corporation accept service of process in order to do business in the state, the Court stated that the consent to do business "may be accompanied by such conditions as Ohio may think fit to impose; . . . provided they are not repugnant to the [C]onstitution or laws of the United States ....."). A specific reference to "unconstitutional conditions" first appears in an 1876 dissenting opinion. See Doyle v. Continental Ins. Co., 94 U.S. 535, 543 (1876) (Bradley, J., dissenting) ("Though a State may have the power ... of prohibiting all foreign corporations from transacting business within its jurisdiction, it has no power to impose unconstitutional conditions upon their doing so."). The dissent was eventually vindicated when the Court's holding in Doyle was overruled in Terral v. Burke Constr. Co., 257 U.S. 529, 533 (1922).

119. 408 U.S. 593, 597 (1972).

120. See Speiser v. Randall, 357 U.S. 513, 526 (1958) ("[The] procedural device [at issue] must necessarily produce a result which the State could not command directly . . . result[ing] in a deterrence of speech which the Constitution makes free."); see also Sullivan, supra note 105, at 1415 (unconstitutional conditions doctrine based on the theory that "government may not do indirectly what it may not do directly"). Professor Epstein describes an unconstitutional conditions problem as arising when "government seeks to achieve its desired result by obtaining bargained-for consent of the party whose [constitutionally protected] conduct is to be restricted" rather than by direct prohibition. Richard A. Epstein, The Supreme Court-1987 Term, Foreword: Unconstitutional Conditions, State Power, and the 
As noted above, ${ }^{121}$ the potential for abuse increased when government became a major provider of benefits, economic and non-economic, during the New Deal era. The government has continued to provide valuable benefits, including licenses permitting activities as varied as selling handguns ${ }^{122}$ to flying certain airline routes, ${ }^{123}$ as well as financial assistance programs for the unemployed and college students. ${ }^{124}$ Whenever the state offers these benefits on the condition that the offeree do something or forgo something in return, there is potential for government exploitation of the individual. When the condition requires the offeree to act or refrain from acting when she has an otherwise constitutionally protected right to do the opposite, an unconstitutional conditions problem arises.

The problem can also be demonstrated by considering the different ways government potentially classifies benefit recipients. One method is to classify people based on immutable characteristics, such as race or gender. The Court has traditionally reviewed these classifications under varying degrees of heightened equal protection scrutiny. ${ }^{125}$ Another method of classification is based on characteristics that people could change, such as behavioral characteristics. This classification has two subdivisions: a class with characteristics that can be changed without implicating constitutional rights and a class with characteristics that can be changed only by implicating constitutional rights. ${ }^{126}$ Courts review the first type of subclassifications only for minimum rationality. ${ }^{127}$ The latter subclassifications present potential problems of unconstitutional conditions. Equal protection is no longer the issue; the focus instead is on the burden placed on the exercise of the right. ${ }^{128}$ Examples of situations presenting potential unconstitutional conditions include classifying medical benefit recipients by whether they choose to give birth or to have an abortion, ${ }^{129}$ welfare recipients by whether they chose to strike or cross the picket line, ${ }^{130}$ or federal arts grant applicants by whether they chose to create "decent" or "indecent" works. ${ }^{131}$

Limits of Consent, 102 HARV. L. REV. 4,7 (1988).

121. See supra note 99 and accompanying text.

122. See 18 U.S.C. $\$ 923$ (1988).

123. See 49 U.S.C. app $\$ 1348$ (1988).

124. See 42 U.S.C. $\$ 503$ (1988) (requirements for unemployment compensation grants to states); 20 U.S.C. \$ 1070-99 (1988) (federal student loan insurance program).

125. See, e.g., Craig v. Boren, 429 U.S. 190 (1976) (permitting sale of 3.2 beer to females 18 and older and males 21 and older violates Equal Protection Clause because classification is not substantially related to achievement of important governmental objectives); Brown v. Board of Educ., 347 U.S. 483 (1954) (holding that racially segregated public schools violate Equal Protection Clause because classification is not narrowly tailored to serve a compelling government interest).

126. Winters, supra note 99 , at 137.

127. See, e.g., Lyng v. International Union, 485 U.S. 360, 364-65 (1988) (treating striking workers different from other unemployed individuals in food stamp program rules satisfies minimum rationality test); Lyng v. Castillo, 477 U.S. 635 (1986) (treating single unit families differently from multiple unit families in food stamp program rules satisfies minimum rationality test).

128. Winters, supra note 99, at 138.

129. Harris v. McRae, 448 U.S. 297 (1980).

130. Lyng, 485 U.S. 360.

131. See supra text accompanying notes $25-30$. 
But just as the right-privilege distinction cannot be accepted at its most expansive interpretation (government always wins when it conditions a benefit), the doctrine of unconstitutional conditions may not be supportable at its broadest formulation (government always loses when a conditioned benefit requires surrender of a constitutional right). Professor Smolla has criticized the label "doctrine" because the doctrine is not applied in a consistent fashion based on discernible principles. The government can in fact impose conditions on recipients of benefits, even conditions that limit constitutional rights they would otherwise be free to exercise. ${ }^{132}$ Many scholars have attempted to resolve the Court's conflicting decisions into a coherent theory that explains when rightinfringing conditions are permitted. Some of these attempts have been comprehensive and persuasive. However, many have been rendered obsolete by the Court's decision in Rust v. Sullivan. ${ }^{133}$ A critique of these scholarly analyses is necessary to understand the Court's decisions and to consider what the Constitution requires.

1. Scholarly Explanations and Proposed Models for Analysis. The unconstitutional conditions doctrine has been analyzed by scholars in a number of different ways. One analysis turns on whether the condition is "coercive." Another asks how germane the condition is to the benefit received, focusing on the motivation of the legislature adopting the conditioned benefit. Still a third looks to the right itself and asks whether permitting this right to be bought and sold, or "commodified," is desirable, or if the right should be inalienable. No single model accurately describes the current state of the law, although each provides insight into the complex nature of the unconstitutional conditions problem that is, in itself, a serious detriment to the free exercise of constitutional rights.

a. Coercion. The Supreme Court has often adopted a coercion test for the constitutionality of a conditioned benefit. If a conditioned benefit is so attractive that it will generally result in a rightholder relinquishing the right to obtain the benefit, the court has held the condition to be unconstitutionally coercive. ${ }^{134}$ Sometimes, however, the condition is considered not so coercive that the rightholder gives up the right; rather, the rightholder chooses to forgo the benefit. This is often labeled a "penalty" on the exercise of the right. ${ }^{135}$ But

132. SMOLLA, supra note 93, at 183. See also Sullivan, supra note 105, at 1415-16 (cases in this area are like "a minefield to be traversed gingerly"); Epstein, supra note 120, at 6 (doctrine has "bedeviled courts and commentators alike" for more than 100 years).

133. 111 S. Ct. 1759 (1991). The Rust decision is discussed extensively in the text accompanying notes 52-77.

134. See, e.g., Speiser v. Randall, 357 U.S. 513, 529 (1958) (coercing veterans into taking oath to obtain tax exemption violates their right not to speak).

135. See, e.g., Attorney General of New York v. Soto-Lopez, 476 U.S. 898, 921 (1986) (O'Connor, J., dissenting) (characterizing plurality opinion as finding preference for New York resident wartime veterans in public employment to be a penalty on nonresidents' right to travel); Memorial Hosp. v. Maricopa County, 415 U.S. 250 (1974) (holding that right to travel is penalized by residence requirement for state medical benefits); Shapiro v. Thompson, 394 U.S. 618, 634 (1969) (exercising right to travel is penalized by statute denying welfare to persons residing in state for less than one year). 
if a condition is considered not to be coercive, it is a "nonsubsidy." Examples of nonsubsidies are the federal government's choices not to fund abortions or to extend tax exemptions to lobbying activities by nonprofit organizations. ${ }^{136}$ The theory is that the rightholders were not coerced by the government since they could seek out alternative sources of funding. In these examples, rather than being coerced into giving up their rights, women and nonprofit organizations were given a choice. On the other hand, an illustration of a penalty was the government's requirement that federally funded, public broadcasters not editorialize on the air. This was considered a penalty because the effect was to coerce the broadcasters into giving up their free speech rights. ${ }^{137}$

In reality, however, the distinction between a penalty and a nonsubsidy is the proverbial line too fine to bear weight. It is dependent on an entirely normative choice as to the starting point, or baseline, of the analysis. The nonsubsidies described above assume as the starting point "funding for birth-related medical expenses" and "exemptions for apolitical activities of nonprofits" respectively. However, if the same analyst chose baselines of "funding pregnancy-related medical expenses" and "exemptions for all nonprofit organization activities," the nonsubsidies can be seen as penalties. The same is true of the penalty for editorials on public broadcasting. If the starting point for analysis is "funding only for noneditorializing public broadcasting" rather than "funding for public broadcasting," the penalty is a mere nonsubsidy.

The folly of employing this mode of analysis becomes clear when one realizes that the government has wide latitude to set the baseline for the analysis. ${ }^{138}$ Since setting the baseline is an outcome-determinative choice, the government will be able to structure its programs to avoid unconstitutionally coercive conditions while significantly hampering the exercise of protected rights. Even so, the petitioners in Rust and the plaintiffs in Finley argued that the decency clause should be invalidated because of its coercive nature. The Rust petitioners argued that the regulations at issue should be invalidated because some Title $X$ recipients would be "forced to choose between a government benefit and a fundamental right," ${ }^{139}$ a classic coercion theory argument. ${ }^{140}$ The Finley plaintiffs, quoting from Rust, argued that the restrictions have the effect of " "prohibiting the recipient from engaging in the protected conduct""141 and that "the 'decency' provision penalizes constitutionally protected speech." 142

136. See Regan v. Taxation with Representation, 461 U.S. 540 (1983); Harris v. McRae, 448 U.S. 297 (1980); As noted above, the labels "penalty" and "nonsubsidy" can also be interpreted as code words for the right-privilege distinction. See supra text accompanying notes 109-17.

137. FCC v. League of Women Voters, 468 U.S. 364 (1984).

138. Sullivan, supra note 105 , at $1450-56$.

139. Brief for Petitioners at 29, Rust v. Sullivan, 111 S. Ct. 1759 (1991) (No. 89-1391).

140. See, e.g., Speiser v. Randall, 357 U.S. 513, 529 (1958).

141. Plaintiffs' Supporting Memorandum at 23, Finley v. NEA, 795 F. Supp. 1457 (C.D. Cal. 1992)

(No. CV 90-5236 AWT) (quoting Rust v. Sullivan, 111 S. Ct. 1759, 1774 (1991)).

142. Id. at 24 (emphasis added). 
b. Germaneness. Another theory advanced to justify the doctrine of unconstitutional conditions is called "germaneness." This theory works by determining whether a right-infringing condition is germane to the purpose of a benefit program, and it has been used to determine the level of deference with which a court will review the condition; the more germane the condition, the more deferential the review. ${ }^{143}$ The rationale underlying the germaneness theory is that an unrelated, or nongermane, condition is evidence of a corrupt or improper legislative process. By attaching the unrelated condition, the legislature is, in effect, engaging in extortion or bribery to achieve results it could not bring about directly. The focus, then, is on a perceived defect in the legislative process rather than on the imposition on individual rights.

Germaneness suffers from a problem similar to that of coercion theory: the purpose of a benefit program can be broadly defined by the government so that a wide range of right-infringing conditions become arguably germane, or related, to the program. As Professor Sullivan has argued, "conditioning food stamps on nonparticipation in labor strikes may be interpreted either as a nongermane condition mixing welfare policy with labor policy, or as a condition germane to welfare policy because it arguably limits [benefits] to those least able to avoid need." 144

c. Inalienability of rights. Another reason offered to justify the doctrine of unconstitutional conditions is that certain rights are inalienable. In other words, by permitting government to purchase rights, rights become just another commodity, like hogs or pollution permits, capable of being sold or transferred at will. The notion that people are born with "inalienable rights" has a long, quasi-sacred history in the United States. ${ }^{145}$ It animates some of the scholarly debate over unconstitutional conditions as well. Treating rights like commodities is antithetical to the belief that certain rights are inalienable. This rationale would direct the protection of the doctrine toward avoiding the societal harm of commodified rights; thus, the focus of this theory is not on protecting an individual's rights. ${ }^{146}$ A person perfectly willing to give up his or her rights in

143. A recent example of this theory in action is the Court's opinion in Nollan v. California Coastal Comm'n, 483 U.S. 825 (1987), where the court held that the condition of an easement over the property for public access to the beach was not germane to the purposes of the construction permit system; therefore, a strict level of review was employed to invalidate the condition.

144. Sullivan, supra note 105, at 1474. Compare Lyng v. International Union, UAW, 485 U.S. 360 (1988) (government may refuse food stamps to striking worker because his unemployment is voluntary) with Sherbert v. Verner, 374 U.S. 398, 419 (1963) (Harlan, J., dissenting) (explaining that the purpose of welfare is not to help those who voluntarily make themselves unavailable for work).

145. See, e.g., THE DeClaration OF INDEPENDENCE (U.S. 1776); SANFORD LEVINSON, CONSTITUTIONAL FATTH (1988).

146. See, e.g., Seth Kreimer, Allocational Sanctions: The Problem of Negative Rights in a Positive State, 132 U. PA. L. REV. 1293 (1984) (arguing that government employees' right to divulge information should be inalienable because it serves a structural interest, that is, informing citizens of the government's activities); Laurence Tribe, The Abortion Funding Conundrum: Inalienable Rights, Affirmative Duties, and the Dilemma of Dependence, 99 HARV. L. REV. 330, 337-38 (1985) (arguing that right to choose 
exchange for a government benefit is not allowed to do so because some other interests are affected by the decision, such as interests in societal structure, the allocation of governmental power, or relations between societal groups or individuals. ${ }^{147}$

Other scholars, arguing against a theory of inalienable rights, consider the doctrine of unconstitutional conditions unnecessary because a person's rights are his or her property to do with as he or she wishes-including selling them to the government for a desired benefit. ${ }^{148}$ The true problem with an inalienable rights theory of unconstitutional conditions, however, is that it is overinclusive. If a right is inalienable, it may not be sold or transferred to anyone. But the doctrine of unconstitutional conditions is directed specifically at conditioned benefits offered by the government. If rights were truly inalienable, private parties would be prevented from conditioning private benefits on the forbearance of a constitutionally protected activity. ${ }^{149}$ Additionally, the Constitution itself contemplates the alienability of rights ${ }^{150}$ as well as the right to choose not to exercise a right (whether made independently or in response to a private inducement). ${ }^{151}$ The flaw with both free-alienability and inalienable rights arguments is that no distinction is made between government and private purchasers of rights. Only governmental attempts to purchase rights implicate constitutional concerns.

d. Professor Smolla's "discernible principles." If the attempt to articulate a coherent rationale for the doctrine of unconstitutional conditions has begun to appear futile, there are prominent scholars who agree. Professor Smolla has characterized unconstitutional conditions as a "sometimes doctrine," stating that it lacks an "organized body of principles applied in a reasonably consistent fashion." 152 His analysis, based in free speech law, focuses on discernible principles that help explain whether right-infringing conditions are permissible.

abortion should be inalienable because it serves a relational function, that is, preventing subjugation of women by men).

147. Another way to conceptualize the idea of inalienability is to consider the ability to purchase another's rights as an offense against the "dignitary interests" of all. See generally Jerry Mashaw, Administrative Due Process: The Quest for a Dignitary Theory, 61 B.U. L. REV. 885 (1981). However, this idea has been soundly criticized as considering only one side of an individual's dignitary interests. Dignity is not enhanced by restricting the individual's choice to alienate a right, even though he or she is otherwise fully competent to engage in contracts. See Epstein, supra note 120, at 12.

148. See generally Frank Easterbrook, Insider Trading, Secret Agents, Evidentiary Privileges, and the Production of Information, 1981 SUP. CT. REV. 309.

149. For example, private employers would not be able to enforce confidentiality agreements if the rightholder's free speech rights were "inalienable."

150. U.S. CONST. amends. V, XIV, $\& 1$ (negative implication of prohibition against government depriving a person of life, liberty or property without due process of law is that the government, with due process of law, may deprive people of property, liberty, or even life).

151. See, e.g., West Virginia State Bd. of Educ. v. Barnette, 319 U.S. 624 (1943) (recognizing student's right not to speak in a manner violating his religious principles, that is, reciting the pledge of allegiance).

152. SMOLLA, supra note 93 , at 183. 
These principles include precision and neutrality, proportionality, relevancy, ${ }^{153}$ professionalism, accommodation, ${ }^{154}$ and licensing. ${ }^{155}$ Evidence of the importance of the precision and neutrality, proportionality, and professionalism principles can be found in the opinions and briefs from Rust, Keyishian, and Finley.

Professor Smolla's precision and neutrality principles require that once the government has authorized a benefit, it cannot withdraw the benefit on the basis of disapproved, but protected, speech. ${ }^{156}$ The Finley plaintiffs argued that the decency clause amounted to viewpoint discrimination, stating that the federal courts have recognized some settings where the First Amendment requires neutrality even when the government is only "declining to support speech rather than prohibiting it altogether."157 Among these settings are the free press, public fora, state universities, and academic research. ${ }^{158}$ Strict government neutrality was required "because [these settings] are "expressly dedicated to speech activity' or are 'traditional sphere[s] of free expression . . . fundamental to the functioning of our society." "159 Similar arguments were advanced unsuccessfully in Rust. Drawing on a line of cases that show a hesitation to approve government regulation of speech or expression that cannot be "justified

153. The relevancy principle is similar to the germaneness theory of unconstitutional conditions discussed above. See supra text accompanying notes 143-44. The relevancy principle requires that restraints placed on speech by participation in a benefit program must advance the goals of that benefit program. Smolla equates this with an intermediate scrutiny test: the condition must be narrowly tailored to effectuate a substantial government interest. SMOLLA, supra note 93, at 189-95. The Court applied this principle in the government employment case of Rankin v. McPherson, 483 U.S. 378 (1987). In that case, Justice Thurgood Marshall turned Holmes's argument in McAuliffe v. Mayor of New Bedford, 29 N.E. 517, 517-18 (Mass. 1892) (discussed supra text accompanying note 96) on its head, holding that an employee of a Texas county constable could not be fired for advocating the violent death of President Reagan. While the court acknowledged that some employees of a law enforcement agency must always exhibit the utmost respect for law, it held the condition on employment unconstitutional because McPherson was a computer operator in a nonpublic part of the office, and any concerns about respect for law were irrelevant to the efficient performance of her job functions.

154. The accommodation principle requires the government to accommodate the exercise of a right even when its primary purpose is not to infringe that right. SMOLLA, supra note 93, at 199-204.

155. Id. at 204-08.

156. See American Council of the Blind v. Boorstin, 644 F. Supp. 811 (D.D.C. 1986) (reversing Library of Congress's decision to stop producing braille versions of Playbay magazine solely because of its sexually explicit content); SMOLLA, supra note 93, at 184 (discussing Boorstin). See also Keyishian v. Board of Regents, 385 U.S. 589 (1967) (discussed supra text accompanying notes 78-90) (implying that state engaged in impermissible viewpoint discrimination by removing professor for mere advocacy of overthrow of government).

157. Plaintiffs' Supporting Memorandum at 25, Finley v. NEA, 795 F. Supp. 1457 (C.D. Cal. 1992) (No. CV 90-5236 AWT).

158. Id. at 25-26 (citing inter alia Arkansas Writers Project, Inc. v. Ragland, 481 U.S. 221 (1987) (holding that tax subsidies to magazines cannot be distributed on basis of content), and Board of Trustees v. Sullivan, 773 F. Supp. 472 (D.D.C. 1991)). See also Plaintiff's Memorandum of Points and Authorities in Opposition to Defendants' Motion for Judgment on the Pleadings at 19, Finley (No. CV 90-5236 AWT) ("[G]overnment may not deny access [to a public forum], a form of subsidy, to any speaker because of the content of his speech.").

159. Plaintiffs' Supporting Memorandum at 25, Finley (No. CV 90-5236 AWT) (quoting Rust v. Sullivan, 111 S. Ct. 1759, 1776 (1991)). 
without reference to the content of the regulated speech," 160 petitioners argued that the Title $\mathrm{X}$ regulations were designed to suppress abortion-related speech as dangerous and to discriminate between family planning programs on the basis of their viewpoint on abortion. ${ }^{161}$

The proportionality principle requires that government's influence over speech be proportionate to the level of its funding. When the level of influence is disproportionate, government is actually regulating the speech, not just choosing whether to subsidize it. ${ }^{162}$ Plaintiffs in Finley and Rust both adopted the proportionality argument. The Finley plaintiffs argued that "the 'decency' provision functions to restrict all of an artist's or art organization's expression, no matter how it is funded, even if the applicant seeks or receives only a small percentage of its funds from the NEA."163 In Rust, petitioners argued that the regulations infringe upon a grant recipient's "ability to engage in the prohibited speech activity "using even wholly private funds."'164 In both cases, speech sponsored by large amounts of private funds either would become dedicated to the government's objectives or be prohibited. As a result, the government exercises an influence over speech by private programs and persons that is disproportionate to the funds it contributes.

Professor Smolla also identifies the professionalism principle as a component of the unconstitutional conditions doctrine. This principle prohibits the legislature from overriding the exercise of professional judgment because, Smolla believes, the likely motivation of such an act is nonneutral viewpoint discrimination. ${ }^{165}$ The Supreme Court has not explicitly endorsed this principle, but the Keyishian decision provides some evidence of the influence of professional judgment on the Court. The Court struck down the statutes in part because of the lack of deference to the judgment of professors teaching their own classes - that is, the lack of respect for academic freedom. ${ }^{166}$ Additionally, contravention of professional judgment may be considered strong evidence of the government's discriminatory intent. ${ }^{167}$

Professor Smolla's loose discernible principles analysis provides a good guide to the considerations that courts find relevant when confronted with a First Amendment unconstitutional conditions problem. Courts, however, often choose not to be bound by guidelines. Smolla even metaphorically threw in the towel in a postscript to his chapter discussing unconstitutional conditions. The

160. Clark v. Community for Creative Non-violence, 468 U.S. 288, 293 (1984). See also Ward v. Rock Against Racism, 491 U.S. 781, 791 (1989).

161. Brief for Petitioners at 15, Rust v. Sullivan, 111 S. Ct. 1759 (1991) (No. 89-1391).

162. SMOLLA, supra note 93, at 189.

163. Plaintiffs' Supporting Memorandum at 24, Finley v. NEA, 795 F. Supp. 1457 (C.D. Cal. 1992)

(No. CV 90-5236 AWT) (emphasis in original).

164. Brief for Petitioners at 24, Rust (No. 89-1391).

165. SMOLLA, supra note 93 , at 196-97.

166. Keyishian v. Board of Regents, 385 U.S. 589, 603 (1967).

167. For example, a plurality of the Court held that a school board may not remove books from school libraries after librarians acquired them and a board-appointed committee approved their retention, both in the exercise of professional judgment. Board of Educ. v. Pico, 457 U.S. 853 (1982). 
Supreme Court, according to Smolla, paid only lip service to the neutrality principle in Rust $v$. Sullivan ${ }^{168}$ and approved Chief Justice Rehnquist's oftadvocated theory that "government may pretty well attach whatever conditions it wants to the receipt of its funds, even when those conditions quite brazenly prefer one set of ideas to another."169 In Smolla's opinion, the Rust decision is simply a new manifestation of the right-privilege distinction, signalling a retreat from "one of the most sophisticated and progressive nuances of modern constitutional law"- the idea that government cannot achieve indirectly what it is prohibited from achieving directly. ${ }^{170}$

e. Professor Sullivan's "systemic account." Professor Kathleen Sullivan has developed a model designed to reconcile the competing purposes of the doctrine that she has called a "systemic account."171 Her approach is based on the proposition that the constitutional rights of individuals implicated in unconstitutional conditions cases protect not only individuals but society at large as well. Constitutional rights, Sullivan argues, "help determine the overall distribution of power between government and rightholders generally, and among classes of rightholders." 172 Infringements of individual constitutional rights, direct or indirect through conditioned benefits, can affect the distribution in three ways. First, the distribution between the government and individual rightholders is changed by transferring to government power over what is usually considered a zone of personal autonomy. Second, facial distributory discrimination results among rightholders themselves because rights are distributed disproportionately among those who do and do not accept the conditions (a violation of government's obligation of neutrality). Third, a conditioned benefit will result in discrimination-in-fact between rightholders by creating "an undesirable caste hierarchy in the enjoyment of constitutional rights" distinguishing those who depend on government benefits and those who do not. ${ }^{173}$ When any of these three concerns are involved in a conditioned benefit case, Sullivan argues that unconstitutional conditions analysis is appropriate.

In practice; Professor Sullivan's systemic approach will capture a greater number of government programs within its net than any one of the theories discussed above. Once the confines of "coercion," "penalty," and "nongermaneness" are left behind, the method of conditioning a benefit becomes irrelevant. The effect on distributive concerns is the focus of the inquiry, and a larger number of programs would be subject to review. ${ }^{174}$ Sullivan proposed strict review "any time a government benefit condition redistributed, or was intended to redistribute, power to government or among rightholders" in the

168. 111 S. Ct. 1759 (1991).

169. SMOLLA, supra note 93, at 217.

170. Id. at 218.

171. Sullivan, supra note 105.

172. Id. at 1490 .

173. Id.

174. Id. at 1499 . 
three ways described above. ${ }^{175}$ The government, of course, would have an opportunity to justify its condition, and often the context of a benefit program alone will be sufficient justification.

Conditioned benefits pressure rights and raise distributive concerns, according to Professor Sullivan, to a level that requires invalidation in the abortion funding cases, which turned on the absence of coercion. ${ }^{176}$ In Professor Sullivan's opinion, lack of coercion should not "immunize" the government's redistributive intent. ${ }^{177}$ The facts of Keyishian, Rust, and Finley also implicate all three distributional concerns: distribution of rights between government and citizen, distribution of rights among individuals based on those who accept and those who reject the conditions, and creation of distributional castes among rightholders based on those who can afford to reject the conditions and those who cannot. On the other end of the spectrum, however, benefit programs that unintentionally alter recipients' choices to exercise constitutional rights need not be struck down as unconstitutional conditions. For example, food stamp coupons must be used to purchase food rather than contraceptives or advertising on radio or television. But such "earmarking" or "in-kind restrictions" do not violate the recipients' rights to privacy or free speech because "such restrictions have so obvious a purpose other than pressuring rights."178

One problem with the systemic account is that, since many cases fall between the polar extremes, effective advocacy can characterize a conditioned benefit either way. Sullivan states that, when it is too difficult to decide where a case falls, courts should err on the side of strict review. ${ }^{179}$ That solution, however, does not move the ball forward. Even if a conditioned benefit pressures rights in a way that raises distributive concerns, the constitutionality of the condition depends on subjective decisionmaking. Courts must still determine if the government's reasons for the condition are compelling. As Sullivan admits, "[o]ne who takes the view that compulsory subsidization of other people's abortions through the tax and transfer system violates the anti-abortion taxpayer's right to free exercise of religion by compelling a violation of conscience" would consider the abortion funding cases correctly decided because the government demonstrated compelling reasons for the redistribution, not simply because there was no coercion. ${ }^{180}$ While the systemic approach may provide a more reasoned and intellectually honest method, it eventually ends up at the same point: a normative judgment. Rather than deciding a conditioned benefit is a nonsubsidy after normatively determining the baseline for the start of the inquiry, the normative judgment in Sullivan's systemic account (as to whether a justification is compelling) comes at the end of the analysis.

175. Id. at 1500 .

176. See Harris v. McRae, 448 U.S. 297 (1980); Maher v. Roe, 432 U.S. 464 (1977).

177. Sullivan, supra note 105 , at 1501 .

178. Id. at 1501 .

179. Id. at 1502 .

180. Id. at 1504-05. 
2. A New Model: Unconstitutional Conditions and Preferred Rights. In the final analysis, most theories of the doctrine of unconstitutional conditions come down to a normative choice that must be made by judges. Such theories are dangerous because they facilitate unfettered discretion. ${ }^{181}$ They are eminently malleable, subject to easy manipulation by an adept advocate. This section offers a model for understanding what is really occurring: individual jurists choose rights or individual applications of rights that they, for whatever reason, prefer, and raise those rights or applications to a preferred status. Rights, or applications of a right with the preferred status, receive the protection of the doctrine of unconstitutional conditions while other rights or applications may be "bought up" with conditioned benefit programs.

What courts have promulgated, in effect, is' a doctrine of unconstitutional conditions, for preferred rights. ${ }^{182}$ The confusion that swirls around this area of the law is engendered not by inconsistent application of the doctrine of unconstitutional conditions, but by political changes that have shifted basic constitutional liberties or specific applications of constitutional rights in and out of the preferred rights category. When discussing the doctrine of unconstitutional conditions, commentators usually mention that an unconstitutional condition seeks exercise or forbearance of a preferred constitutional right in exchange for a benefit. ${ }^{183}$ However, they generally spend little effort, if any, distinguishing preferred rights from other rights. ${ }^{184}$

The most interesting cases demonstrating distinctions between preferred rights and nonpreferred rights have occurred after the Warren Court's focus on individual rights was given a lower priority by succeeding courts. ${ }^{185}$ In these

181. Most constitutional law scholars agree that there are guiding principles that courts should observe when interpreting the Constitution. See generally ROBERT H. BORK, THE TEMPTING OF America: The Polttical Seduction of the Law (1990); JoHn Hart Ely, Democracy and Distrust: A THEORY OF JUdiCIAL REVIEW (1980); M. PERRY, THE CONSTITUTION, THE COURTS AND HUMAN RigHTS: AN INQUIRY INTO THE LEGITIMACY OF CONSTITUTIONAL POLICYMAKING BY THE JUDICIARY (1982); Thomas Grey, Do We Have an Unwritten Constitution?, 27 STAN. L. REV. 703 (1975); and H. Jefferson Powell, The Original Understanding of Original Intent, 98 HARV. L. REV. 885 (1985). The perception that such principles are not observed results in "the crude popular mistake that some judges obey the Constitution and others disregard it." See DwORKIN, supra note 10, at 359-60 (discussing the difference between interpretivist and noninterpretivist judges).

182. The Supreme Court has referred to the rights embodied in the First Amendment as holding a preferred position. See West Virginia State Bd. of Educ. v. Barnette, 319 U.S. 624, 639 (1943); Murdock v. Pennsylvania, 319 U.S. 105, 115 (1943); see also Jones v. Opelika, 316 U.S. 584, 608 (1942) (Stone, C.J., dissenting). But see United States v. Carolene Products Co., 304 U.S. 144, 152-53 n.4 (1938) (indicating that all specific prohibitions within Bill of Rights might occupy a preferred position). Subsequent cases show that not all First Amendment rights are preferred while rights other than those in the First Amendment are treated as preferred. See, e.g., Rust v. Sullivan, 111 S. Ct. 1759 (1991).

183. See, e.g., Winters, supra note 99, at 134 (opining that Rust indicates the Court's "intention to treat nearly all benefit allocations whose distributional criteria refer to the exercise of preferred rights the same as it would treat allocations based on immutable characteristics," without elaborating on the scope of preferred rights).

184. See, e.g., Sullivan, supra note 105 , at 1490 ("Preferred constitutional liberties generally declare desirable some realm of autonomy that should remain free from government encroachment.").

185. See, e.g., Jerold H. IsRael \& Wayne R. LaFave, Criminal Procedure $\$ 2.7$, at 75 (2d ed. 1992) (noting that commentators divide over whether Burger and Rehnquist courts have only slowed 
cases, positive rights were not wholly vitiated, but the federal government's power to indirectly achieve what it would be prohibited from achieving directly was increased. ${ }^{186}$

Perhaps the strongest example of a right that is not preferred is the right to choose an abortion. Although the right has been severely limited since the 1973 Roe v. Wade ${ }^{187}$ decision, it nonetheless remains a right. ${ }^{188}$ Its status as a nonpreferred right, however, has permitted the government to condition welfare program medical benefits for women on the surrender of the right. ${ }^{189}$ Women who were eligible for welfare medical benefits were left to the private market to obtain an abortion, which they could not utilize for the same lack of money that made them eligible for medical benefits in the first place. The benefit of medical care was available only on the condition that the woman carried the child to term and relinquished her right to choose an abortion. The obvious and inevitable result of this program allows government to achieve indirectly what it could not achieve directly at least with respect to women financially dependent on the government.

The Supreme Court has even held that the government is permitted to require family planning clinics not to engage in activities advocating abortion if they accept federal funding. ${ }^{190}$ This demonstrates that even certain applications of the right to free speech can be nonpreferred. The government may constitutionally seek abandonment of the right to speak freely about abortion in exchange for government benefits, even though it may not seek the abandonment of the right to speak freely about communism in a state university. The Court, in fact, has all but admitted the existence of a hierarchy of free speech

the momentum of expanding constitutional guarantees or begun a partial retreat).

186. One example of this phenomenon can be seen in cases involving the right to travel. The government may not directly prohibit a citizen, without due process of law, from travelling between states or internationally. See Zemel v. Rusk, 381 U.S. 1, 14 (1965) (international travel); Edwards v. California, 314 U.S. 160 (1941) (striking down California law that criminalized assistance to known indigents migrating into California from other states); see generally Daniel Farber, National Security, The Right to Travel, and the Court, 1981 SUP. CT. REV. 263. These rights may, however, be infringed by benefits conditioned on the surrender of the right to travel. See Haig v. Agee, 453 U.S. 280 (1981) (upholding revocation of passport of former CIA official who fled to West Germany and declared his intention to expose CIA operations despite the burden imposed on international travel); Sosna v. Iowa, 419 U.S. 393 (1975) (approving one-year residency requirement for citizens seeking a divorce in state courts); Rosario v. Rockefeller, 410 U.S. 752 (1973) (requiring registration and, therefore, residency to vote in a primary almost a year in advance is constitutional); Starns v. Malkerson, 401 U.S. 985 (1971), summarily aff g, 326 F. Supp. 234 (D. Minn. 1970) (approving state requirement of one year of residency before qualifying for in-state tuition rate at state university). The right to travel, therefore, is not considered a preferred right. But see Memorial Hosp. v. Maricopa County, 415 U.S. 250 (1974) (striking down statute requiring one-year residency for nonemergency publicly funded medical treatment); Vlandis v. Kline, 412 U.S. 441 (1973) (invalidating statute permanently barring nonresident students from becoming residents for purposes of in-state tuition rate); Dunn v. Blumstein, 405 U.S. 330 (1972) (striking down one-year residency requirement for voter registration).

187. 410 U.S. 113 (1973).

188. Casey v. Planned Parenthood, 112 S. Ct. 2791, 2812 (1992) (reaffirming central holding of Roe v. Wade).

189. See Harris v. McRae, 448 U.S. 297 (1980); Maher v. Roe, 432 U.S. 464 (1977).

190. Rust v. Sullivan, 111 S. Ct. 1759, 1776-78 (1991). See also supra text accompanying notes 52-77. 
rights in its Keyishian and Rust opinions. The Court's decision in Keyishian was clearly influenced by the nature of the rights involved. Free speech generally and academic freedom particularly were lauded in the Court's opinion as preferred constitutional rights. The court stated that " $[\mathrm{t}]$ eachers and students must always remain free to inquire, to study and to evaluate, to gain new maturity and understanding; otherwise our civilization will stagnate and die."”191 To emphasize its point, the Court reiterated that "'[p]recision of regulation must be the touchstone in an area so closely touching our most precious freedoms."'192 In Rust v. Sullivan, the Court attempted to distinguish Keyishian on the nature of the free speech right involved. The Court stated that it had "recognized that the university is a traditional sphere of free expression so fundamental to the functioning of our society that the Government's ability to control speech within that sphere by means of conditions attached to the expenditure of Government funds is restricted by ... the First Amendment." ${ }^{193}$

The free exercise of religion, on the other hand, is usually considered a preferred right. ${ }^{194}$ Under a recent Supreme Court decision, however, the free exercise of Native American religion may not be a preferred application of the right. ${ }^{195}$ Employment Division v. Smith ${ }^{196}$ evinced a "troubling lack of sensitivity by the Court to the free exercise of religion, particularly of non-mainstream groups such as the Native Americans." ${ }^{197}$ In that case, the Supreme Court held that Oregon could refuse to pay unemployment benefits to individuals dismissed from their jobs for religiously motivated use of peyote, a drug proscribed by state criminal law. ${ }^{198}$ This result was announced in spite of consistent efforts by the courts to vindicate the free exercise of religion generally in the context of government benefit programs. ${ }^{199}$ The Court purported to distinguish Smith from this line of cases by pointing to the fact that any use of peyote was in violation of a state criminal law of general applicability. ${ }^{200}$ However, a state

191. Keyishian v. Board of Regents, 385 U.S. 589, 603 (1967) (quoting Sweezy v. New Hampshire, 354 U.S. 234, 250 (1957)).

192. Id. (quoting NAACP v. Button, 371 U.S. 415, 438 (1963)).

193. Rust, 111 S. Ct. at 1776 (citing Keyishian, 385 U.S. at 603, 605-06).

194. See, e.g., Wisconsin v. Yoder, 406 U.S. 205 (1972) (striking down criminal penalty imposed on Amish parents who kept their children out of public school for religious reasons); see also Murdock $\mathbf{v}$. Pennsylvania, 319 U.S. 105, 115 (1943) (dictum) ("[F]reedom of religion [is] in a preferred position.").

195. There is also evidence suggesting that the free exercise of Native American religion may not be preferred outside the context of conditioned benefits. See Lyng v. Northwest Indian Cemetery Protective Ass'n, 485 U.S. 439, 442 (1988) (allowing government to issue timber harvesting permits for an area where the harvesting would destroy a religious worship site "integral and indispensable" to three Native American tribes).

196. 494 U.S. $872(1990)$.

197. SMOLLA, supra note 93, at 202.

198. Smith, 494 U.S. 872.

199. See, e.g., Hobbie v. Unemployment Appeals Comm'n, 107 S. Ct. 1046 (1987) (denying unemployment benefits to Seventh-Day Adventist who refused to work on religion's Sabbath was an unconstitutional condition even though she changed religions after starting her employment); Sherbert v. Verner, 374 U.S. 398 (1963) (denying unemployment to Seventh-Day Adventist who refused to work on religion's Sabbath was an unconstitutional condition).

200. 494 U.S. at 877-80. 
criminal law of general applicability did not stop the Court from overturning the convictions of Amish parents who would not enroll their children in public school for religious reasons. ${ }^{201}$ Essentially, Amish free exercise is preferred to Native American free exercise even though both manifestations of the right violated state criminal law.

The preferred rights model of unconstitutional conditions exposes the current practice of the Supreme Court to be exactly what it is: illegitimate exercise of unfettered discretion in order to reach a result that protects those rights that the Court subjectively prefers while vindicating the government's indirect regulation of nonpreferred rights. In many cases, the distinctions made by the Court's decisions amount to a violation of the equal protection component of the federal Due Process Clause. ${ }^{202}$ For example, distinguishing between free exercise by Amish and free exercise by Native Americans ${ }^{203}$ or between speech about abortion and speech about public issues ${ }^{204}$ is patent viewpoint and content discrimination. Each exercise of an individual right must be given the same level of constitutional protection.

The ramifications of preferred right or preferred application status were obvious to plaintiffs and the district court in Finley. Both the court's opinion and plaintiffs' brief attempted to characterize artistic freedom as being closer to academic freedom than to the freedom of speech in government-funded family planning clinics. ${ }^{205}$ It is not so clear, however, that artistic expression is more like academic freedom than the First Amendment issues involved in Rust. The artistic expression in Finley was, by definition, potentially indecent artwork. A great many U.S. citizens would not choose to give such artwork the same protection as academic lectures. As a result, the answer to the question presented in Finley depends to a large extent on the subjective view of the presiding judge or justices rather than the law of unconstitutionally conditioned benefits.

201. Wisconsin v. Yoder, 406 U.S. 205 (1972).

202. U.S. CONST. amend. V. The essence of the Equal Protection Clause of the Fourteenth Amendment, applicable to the states, has been "reverse incorporated" in the Due Process Clause of the Fifth Amendment, applicable to the federal government. See Bolling v. Sharpe, 347 U.S. 497, 499-500 (1954).

203. Compare Wisconsin v. Yoder, 406 U.S. 205 (1972) (requiring students to attend school, and fining parents for violations, infringes free exercise right) with Employment Division v. Smith, 494 U.S. 872 (1990) (prohibiting use of peyote and denying unemployment benefits for such use does not infringe free exercise right).

204. Compare Rust, 111 S. Ct. 1759 (holding that family planning funding could be withdrawn for advocating abortions) with Rankin v. McPherson, 483 U.S. 378 (1987) (holding that benefit in form of public employment as a clerical employee of a Texas county constable, to whom there was no public access, could not be withdrawn for advocating the violent death of President Reagan).

205. See supra text accompanying notes $37,45-47$. 


\section{IV \\ CONCLUSION}

The current state of the law applies the doctrine of unconstitutional conditions to some cases and the right-privilege distinction to others. This inconsistency is undesirable for a number of reasons. First, it permits judges a great deal of leeway in passing judgment on conditioned benefit programs, leading to a cynical lack of confidence in the courts and charges of judicial activism. Well-trained advocates and judicial opinion writers can easily mold a problem to fit either analysis, producing an outcome based not on the law but, consciously or unconsciously, on a judge's subjective biases and prejudices. Second, it confounds scholars and courts alike because it is difficult to apply, thus creating inconsistency and unpredictability in the law. An artist with an NEA grant, for example, must proceed carefully when painting, writing, or performing at the cutting edge of his or her profession for fear of straying across the lessthan-clear boundary of "decency." It is the brave artist, lacking other means of comprehensive support, who freely expresses his or her beliefs or emotions through art at the risk of losing that support. The distributional concerns raised by Professor Sullivan are a reality, regardless of the ultimate outcome of Supreme Court litigation over the decency clause, because the uncertainty in the law of unconstitutional conditions results in hesitant artistic expression rather than bold ventures that challenge the limits of traditional artistic forms. Because the government's actions are not clearly legitimate or illegitimate, the government has the power to restrain artists from exercising their right to express themselves. Even a temporary restraint on individual freedoms, lasting until the Supreme Court makes a definitive decision on the issue, is itself an unacceptable perversion of the Constitution.

The dilemma of the conscientious artist, desiring to remain eligible for federal funding, can be repeated in scores of different benefit programs. The law student receiving financial aid or the state university law professor may hesitate to criticize the Republican Form of Government Clause if Congress conditions aid or the state conditions employment on an oath to uphold it. The dilemma is exacerbated if government's power to do so is indeterminate, being neither clearly prohibited or permitted. Similarly, if the government conditions the receipt of social security benefits or public housing on an agreement to surrender the Second Amendment right to bear arms, and its authority to do so is unclear, many people will choose not to exercise their right in order to protect their benefit payments. Whether the law is eventually upheld or struck down, the uncertainty in the law results in a "chilling" of the impulse to engage in constitutionally protected activities.

Criticizing the uncertainty of the law because of its chilling effect on the exercise of constitutional rights does not preordain any single denouement. There are two potential solutions that would resolve the uncertainty, but each would have drastically different consequences for government power and 
individual rights. Nonetheless, either of these solutions is preferable to the minefield of the "sometimes" doctrine of unconstitutional conditions. ${ }^{206}$

By virtue of the first potential solution, the government could be permitted to purchase rights with impunity. The participation in any benefit program, in contradistinction to prohibitory statutes backed by criminal or civil penalties, could be conditioned on the surrender of constitutional rights. The doctor seeking a state license to practice medicine could be required to give up his or her right to just compensation when the government takes the doctor's "property" in the form of required service in low-income, inner-city neighborhoods. The law student seeking financial aid could be constitutionally required to give up the right to speak freely; the retired laborer could be constitutionally required to give up the right to bear arms in order to receive social security; and the artist seeking an NEA grant could be constitutionally required to give up his or her right to create indecent work, whether funded by the grant or not. In other words, the fact that some of the food in Little Red Riding Hood's basket was originally provided by the Big Bad Wolf would be given full recognition and the Big Bad Wolf's conditions would have to be observed. This option would represent the farthest possible extension of the right-privilege distinction.

At first glance, this result seems almost fascist; but it is not nearly so evil. As in other facets of constitutional law, rights in this context would be safeguarded by the political process. ${ }^{207}$ Outrageous conditions, such as the surrender of all constitutional rights in order to obtain a passport, would not be attached to government programs because they would be unpopular with voters and, thus, unlikely to be adopted by Congress and signed into law by the president. If such conditions were attached, public indignation would result in the ouster of politicians who had supported the unpopular acts. Additionally, this approach fully embraces the negative rights view of the Constitution ${ }^{208}$ (the deeply held belief of generations of U.S. citizens that the Constitution protects individuals

206. Any one person's solution of choice depends on that person's theory of the Constitution. Those individuals who view the Constitution solely as a charter of negative rights vis à vis the government will choose the first solution while those who see positive entitlements in the document will choose the second. An attempt to influence anyone's fundamental view of the Constitution is beyond the scope of this article.

207. The political process is the only protection states can claim against federal regulation under the Tenth Amendment. See, e.g., Garcia v. San Antonio Metro. Transit Auth., 469 U.S. 528,552 (1985) (holding that Congress may regulate states, even when engaged in traditional governmental functions, under the affirmative power of the commerce clause and to the full extent of that power because states can effectively protect themselves through the "federal political process"). Similarly, certain types of government action that may be unconstitutional and that sometimes have the effect of infringing the rights of individuals have been held to be "nonjusticiable" by the Supreme Court, leaving resolution to the political branches of government. See, e.g., Gilligan v. Morgan, 413 U.S. 1 (1973) (holding that action initiated by Kent State University students in aftermath of shooting of four students in an anti-Vietnam War protest for injunctive and declaratory relief based on grossly inadequate training of the National Guard is a nonjusticiable political question); Luther v. Borden, 48 U.S. (7 How.) 1 (1849) (holding, in prosecution for participation in an illegal election, that defendant's claim that government of Rhode Island was not republican in form, as required by Article IV, $\S 4$ of the Constitution, was a nonjusticiable political question); see also ERWIN CHEMERINSKY, FEDERAL JURISDICTION § 2.6, at 124-45 (1988).

208. See supra text accompanying notes $115+17$. 
from government encroachments on personal liberty but does not create an affirmative right to entitlements). However, the approval of this solution would be met with deep criticism by civil libertarians who would undoubtedly find it insufficiently Cerberean of individual rights. Citizens forced to choose between benefits and constitutional rights could not even state a claim for vindication of their protected interests.

Under the second possible solution, the government would not be able to "deny a benefit to a person on a basis that infringes his constitutionally protected interests." 209 Under this doctrine of unconstitutional conditions, the government would bear the risk of dancing too close to protected liberties with conditioned benefit programs. ${ }^{210}$ Any condition that infringed a constitutional right would be void. The clinic employees in Rust $v$. Sullivan would be permitted to discuss abortion with patients, and the nonprofit organizations in Regan $v$. Taxation with Representation would be allowed to lobby Congress without setting up separate, affiliate organizations. In other words, the items in Little Red Riding Hood's basket would be recognized as hers to do with as she wishes, regardless of the conditions promulgated by the Big Bad Wolf if these conditions prevent her from engaging in a constitutionally protected activity. This option would extend the doctrine of unconstitutional conditions to its logical conclusion, requiring that Congress not impose any conditions infringing constitutionally protected activities of beneficiaries at any time or in any place. ${ }^{211}$

A comprehensive doctrine of unconstitutional conditions would put legislators on notice of their constitutional choices. They could choose either to create the program without unconstitutional conditions or to not adopt the program at all. Additionally, the government would not be foreclosed from imposing any condition on benefit programs. Food stamps, for instance, could still constitutionally be limited to food purchases as "in-kind restrictions"212 that do not prevent the recipient from exercising a right at any time or in any place. But when the conditions approach individual rights and are prohibited by the extended doctrine, such as requiring that cash grants to indigent persons not be used to purchase advertising time on radio or television, often there will be other factors that will make the conditions unnecessary. For instance, the indigent

209. Perry v. Sindermann, 408 U.S. 593, 597 (1972).

210. Cf. Boyce Motor Lines v. United States, 342 U.S. 337, 340 (1952) (refusing to hold Interstate Commerce Commission regulations concerning the transportation of explosives invalid for vagueness, Justice Clark wrote, "Nor is it unfair to require that one who deliberately goes perilously close to an area of proscribed conduct shall take the risk that he may cross the line ....").

211. This article does not discuss in detail what, if any, limitations exist on the government when it acts as a participant in the marketplace of ideas. See supra text accompanying notes 67-69. This article assumes, however, that even if the government could not impose conditions that infringe protected activities, the government could still purchase speech. The government may require employees to support its policies, purchase advertisements promoting alternatives to abortion, and commission art for federal buildings that meets the guidelines of the decency clause. In such cases, however, the government is making its own statement and paying the full cost of that expression, and the government is not infringing the constitutional rights of anyone by controlling its own speech. See also supra text accompanying notes 162-64 (Professor Smolla's proportionality principle).

212. See Sullivan, supra note 105, at 1501. 
receiving welfare will probably choose to eat rather than saving the money over weeks or months or years to buy some sort of advertising. Just as individual rights under the first potential solution would be protected by the political process, here the integrity of government programs could generally be protected by the conditions of the real world. Most often, benefit recipients will use the benefits for the purpose intended. But, if they do use the benefit for an unintended, though constitutionally protected, activity, the government would not be able to complain, except by terminating the program. Obviously, this solution is extremely protective-some would argue overprotective-of individual constitutional liberties. The drawback to this solution is that, without the ability to place conditions on the programs or program recipients, the legislature may choose not to provide the benefit program at all. So while the NEA would be prohibited from denying grants to artists whose work did not conform to the "general standards of decency ... of the American public,"213 it is possible that some future Congress would not reauthorize the continuation of the NEA under those circumstances. Detractors would also argue that by requiring the government to place no conditions on government benefits, this solution does not give the government enough latitude to provide the benefits and services expected of it.

In sum, neither option is perfect and both are subject to criticism. However, both are preferable to the current state of the law. Either could be explained in an intellectually honest fashion, and either could be consistently applied by courts. The status quo permits an unconstitutional conditions problem to be resolved either for or against the government by employing a subjective analysis and an easily manipulated set of Supreme Court precedents that provide supporting language for both outcomes. Such absolute judicial discretion is unworthy of the Constitution. Either potential solution offered in this article would recognize the Constitution's character, both as a grant of limited and defined power from the people to the government and as the "supreme Law of the Land,"214 and each would restore the rule of $\mathrm{law}^{215}$ in the context of conditioned benefits.

213. 20 U.S.C. \& 954(d) (1990).

214. U.S. CONST. art. VI.

215. Professor Dworkin argues that the rule of law requires government to treat people with integrity by speaking "with one voice," acting "in a principled and coherent manner toward all its citizens," and extending "to everyone the substantive standards of justice or fairness it uses for some." DWORKIN, supra note 10 , at 165 . 
